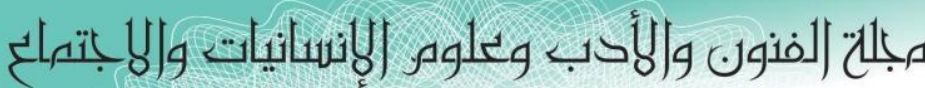

Journal of Arts, Literature, Humanities and Social Sciences

ISSN online: 2414 - 3383

ISSN print: 2616 - 3810

2019 نوفوبر

Volume (45)

العدد (45)

November 2019

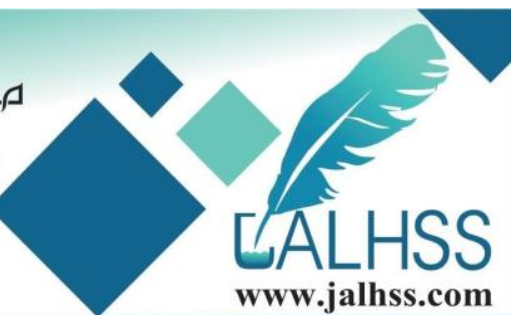

\title{
الصمت الزواجي وعلاقته بالرضا عن الحياة
}

\author{
د. إيمان عبيد الرفاعي

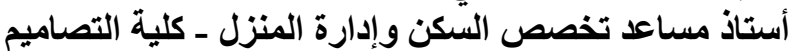 \\ جامعة أم القري - المملكة العربية السعودية المنزية
}

تعتبر حالة الصمت الزو اجي من الظو اهر المستجدة التي تلقي بظلالها السلبية على مناخ العلاقات الزو وبية بين

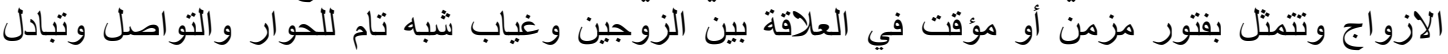

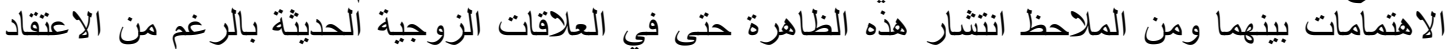

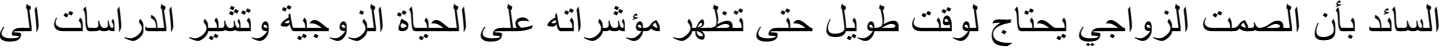

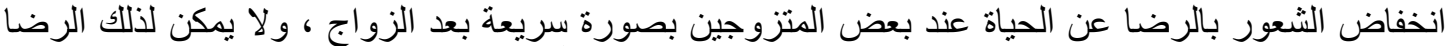

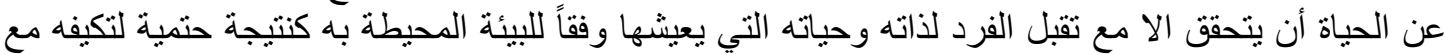

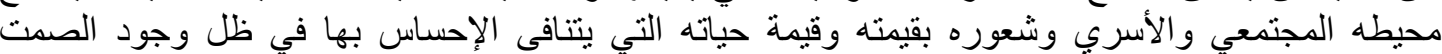
الزواجي.

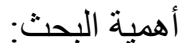
1. تتمثل الأهمية النظرية في الإضافة التي يمكن أن يقدمها البحث وذللك لخصوصية التناول حيث تعتبر ظاهرة

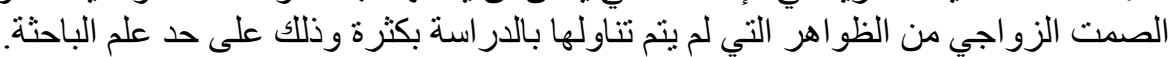

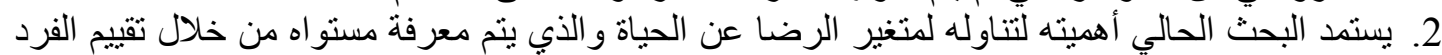

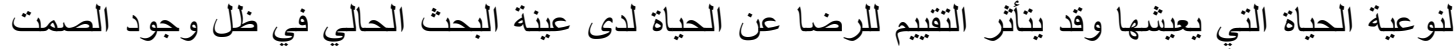

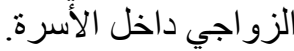

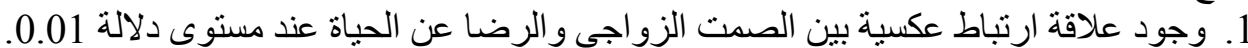
2. وجود فروق ذات دلالة إحصائية بين متوسط درجات أفر اد العينة في الصمت الزيات الزواجي تبعا لـتغيرات

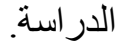
3. وجود فروق ذات دلالة إحصائية بين متوسط درجات أفراد العينة في الرضا عن الحياة تبعاً لمتغيرات

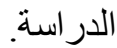

توصيات الدر اسة: 1. العمل على توفير الييئة الحوارية المحفزة للتواصل الزواجي وذللك بتحديد مساحة زمنية للنقاش وتبادل

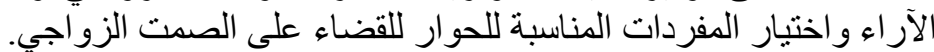

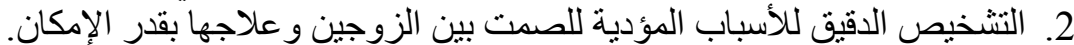

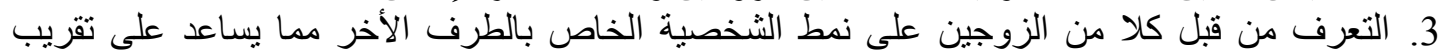

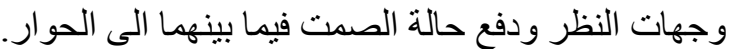

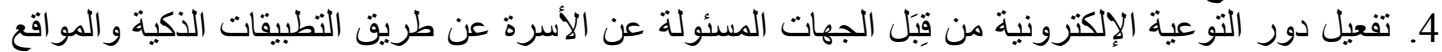

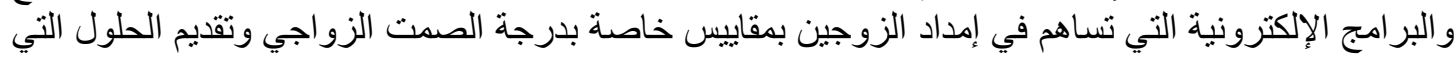
تساهم في القضاء عليه. 


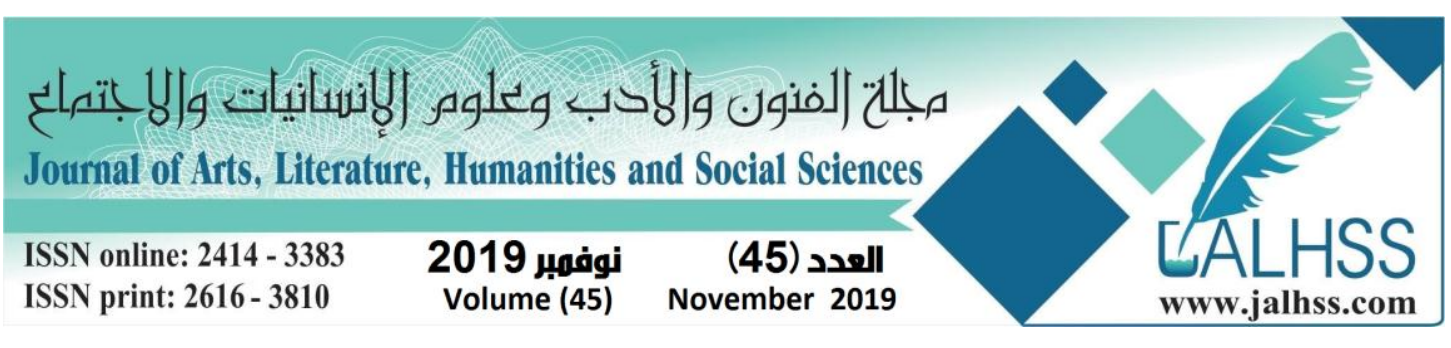

\title{
Marital Silence and its Relationship to Complacency about Life
}

\section{Dr.Iman Obaid Al-Rifae}

\begin{abstract}
The situation of marital silence is an emerging phenomenon that casts a negative shadow on the atmosphere of marital relations between couples and is characterized by a chronic or temporary chill in the relationship between the spouses and the absence of almost complete dialogue and communication and exchange of interests between them. Marital needs a long time to show signs of marital life and studies show a decrease in satisfaction with life in some married couples quickly after marriage, and that satisfaction with life can be achieved only with the acceptance of the individual and his life According to the surrounding environment as an inevitable result of its adaptation to the community and family and a sense of value and the value of life, which is incompatible with the sense of marital silence.
\end{abstract}

research importance:

1. The theoretical importance is in the addition that can be provided by the research to the specificity of handling, where the phenomenon of marital silence is one of the phenomena that have not been dealt with much study, to the knowledge of the researcher.

2. The current research derives its importance to address the variable of satisfaction with life, which is defined by the individual's assessment of the quality of life lived and may be affected by the assessment of satisfaction with life in the current research sample in the presence of marital silence within the family.

research results:

1. An inverse correlation between marital silence and life satisfaction at the level of 0.01 .

2. There are statistically significant differences between the mean scores of the sample in marital silence according to the study variables.

3. There are statistically significant differences between the average scores of the sample in life satisfaction according to study variables.

Study Recommendations:

1. Working to provide a stimulating dialogue environment for marital communication by defining a time space for discussion and exchange of views and selecting appropriate vocabulary for dialogue to eliminate marital silence.

2. Accurate diagnosis of causes leading to silence between spouses and treatment as much as possible.

3. Identification by both spouses on the pattern of personality of the other party, which helps to bring the views and push the state of silence between them to dialogue.

4. Activating the role of electronic awareness by the bodies responsible for the family through smart applications, websites and electronic programs that contribute to providing the spouses with special standards of marital silence and providing solutions that contribute to its elimination. 


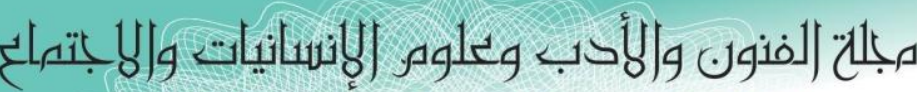
Journal of Arts, Literature, Humanities and Social Sciences

ISSN online: 2414 - 3383

ISSN print: 2616 - 3810

نوفمبر 2019

Volume (45)
العدد (45)

November 2019

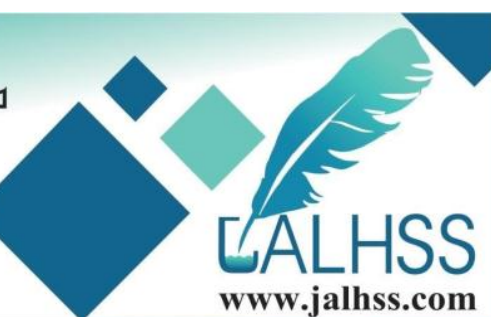

المقدمة

العلاقة الزوجية من أسمى العلاقات الإنسانية فعليها يقوم بناء مجتمع بأكمله وبمدى التواصل بين الزوجين

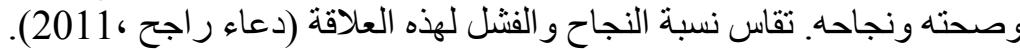

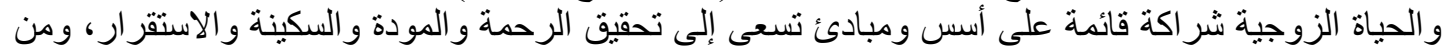

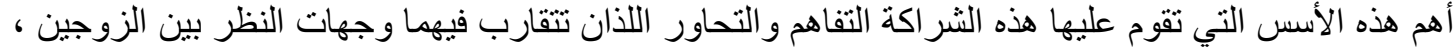
وتتسع معها المفاهيم و المدركات لتجاوز خلافاتهما والتغلب على الظروف التهي قد تو اجهرما ، كما يعدان وسيلة

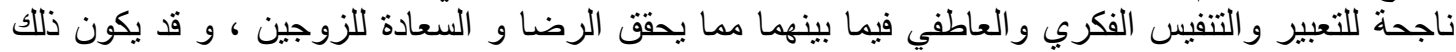

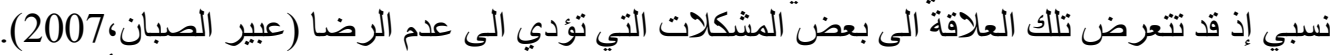

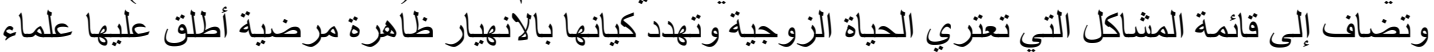
الاجتماع وأخصائيو الصحة النفسية اسم مرض الصمت الزوب اجي أو أو الخرس الزوجي أو السكتة الزوجية أو الطلاق النفسي.

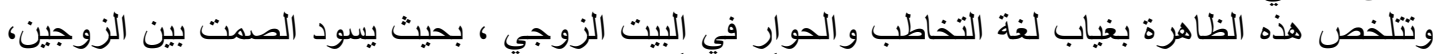

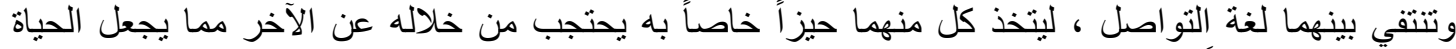

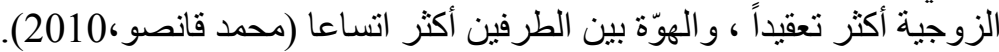

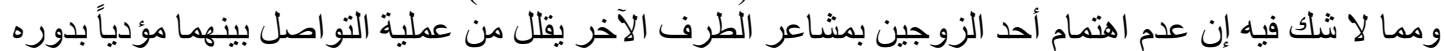

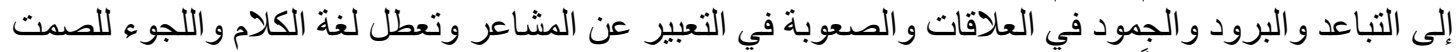
الزواجي الذي يؤثر سلباً على الاسرة بشكل خاص ود علّى الحياة الزوجية بشكل عام (نبيل الجندي ومها أبو زنيد

.2017،

ويشير يوسف عواد (2015) إلى أن هذا النوع من الصمت ينتاب الحياة الأسرية لأسباب نفسية ولا يوجد للعو امل البيولوجية سبب في في ذلك. هذا و تؤكد الدر استات أن من أهم أسباب الطلاق المبكر انعدام الحوار بين الزوجين المتمثل في الصمت الزواجي

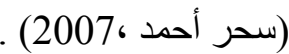

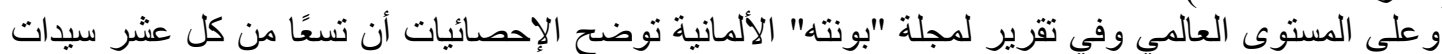

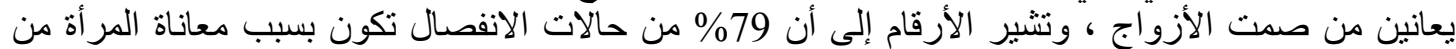

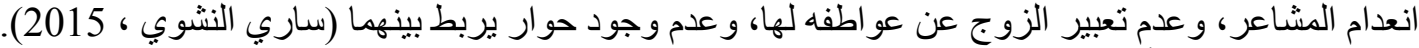

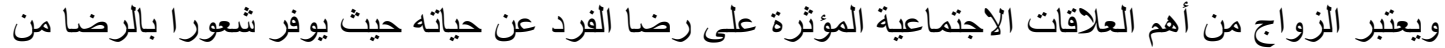

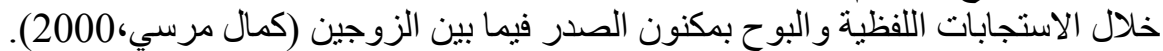

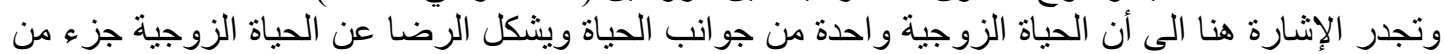
الرضنا الكلي عن الحياة (pinquart \& Teubert , 2010). ويعتبر الشتور بالرضا عن الحياة أحد المكونات الأساسية للسعادة ويعتبر الأشخاص الذين الذين يتمتعون بحياة زوجية سعيدة هم أكثر الناس رضئ الرون عن الحياة (مكفس عبدالملك ، 2018). ويعد الرضا عن الحياة قمة مطالب الحياة الإنسانية ويتمثل في السعادة والاحساس بالارنياة الإنياح عن نوعية الحياة

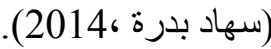

وتبرز أهمية الرضا عن الحياة لما له من دور في تكوين مشاعر الفرد عن نشاطاته وأحداث حياته وتوجهاته مما

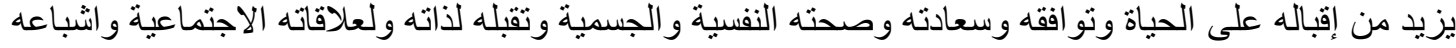

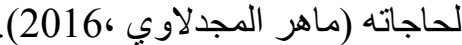
ومن هنا نبعت فكرة البحث الحالي للتعرف الته على أثر الصمت الزواجي على الرضا عن الحياة.

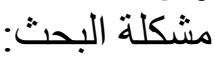

تعتبر حالة الصمت الزو اجي من الظواهر المستجدة التي تلقي بظلالها السلبية على مناخ العلاقات الزوجية بين

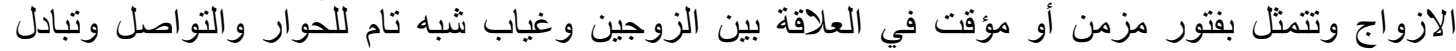
الاهتمامات بينهما ومن الملاحظ انتشار هذه الظاهرة حتى في العلاقات الزورجية الحديثة بالر غم من الاعتقاد

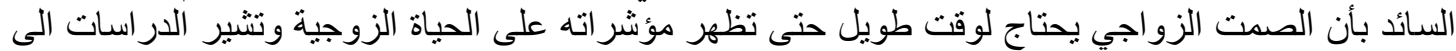

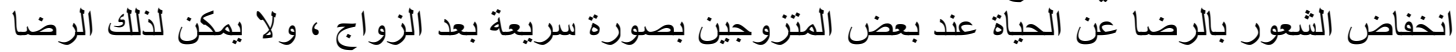




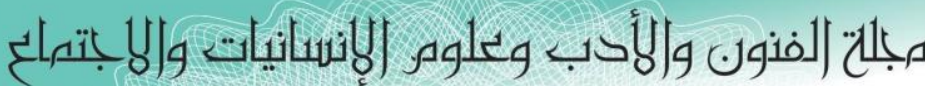

Journal of Arts, Literature, Humanities and Social Sciences

ISSN online: 2414 - 3383

ISSN print: 2616 - 3810

2019 نوفهبر

Volume (45)
العدد (45)

November 2019

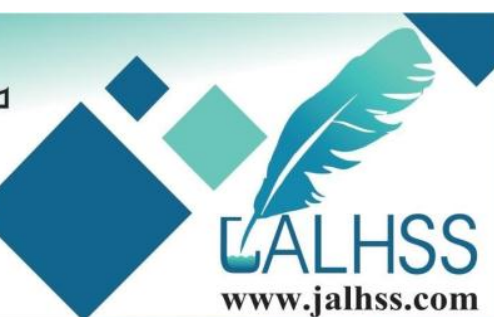

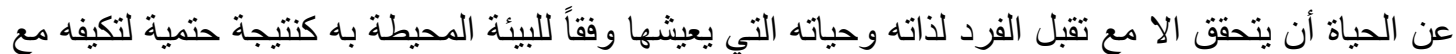

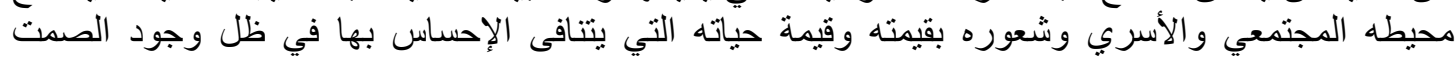
الزواجي. وفي ضوء ما سبق تتمثل مشكلة البحث في التساؤلات التالية:

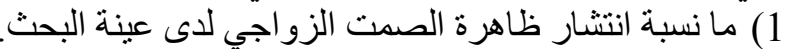

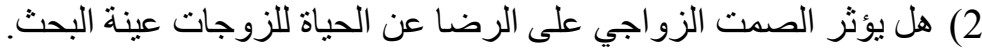

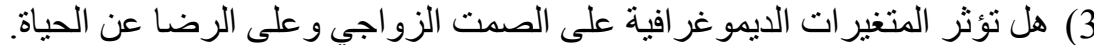

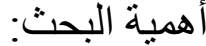

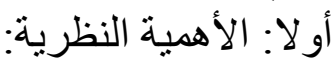
1. تتمثل الأهية النظرية في الإضافة التي يمكن أن بقدمها البحث وذلك لخصوصية التهبة التناول حيث تعنبر ظاهرة

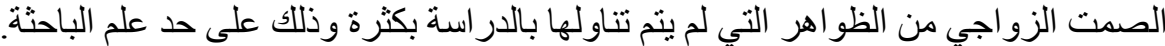

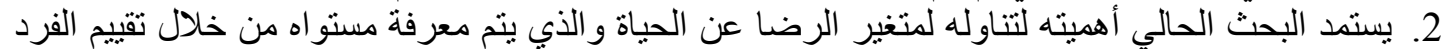

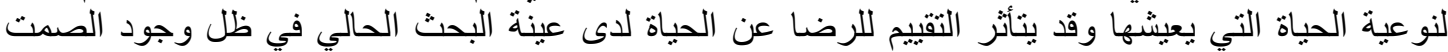

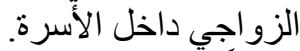
ثانياً : الأهمية التطبيقية:

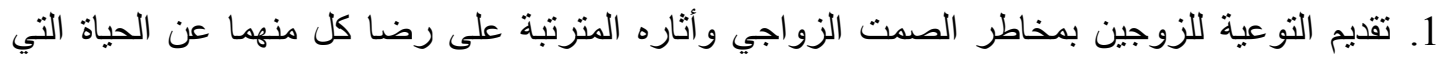

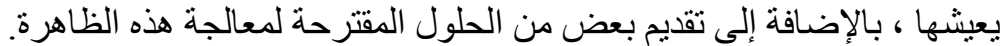

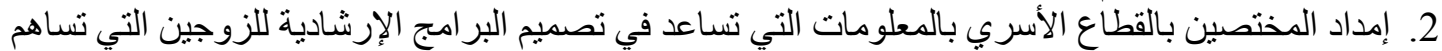

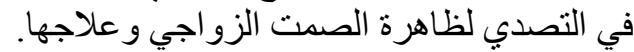

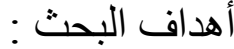

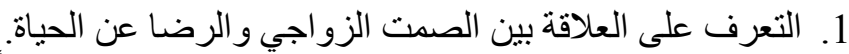

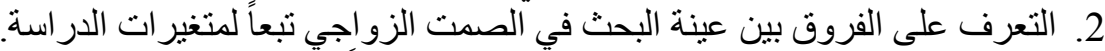

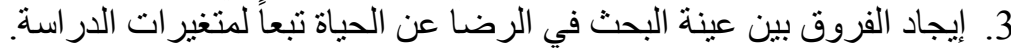

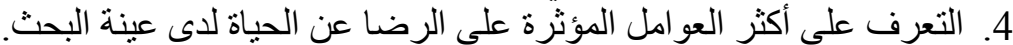

5. الكثف عن أولويات محاور الرضا عن الحياة المؤثرة على عينة البرة البحث.

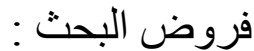

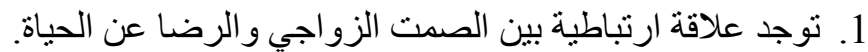

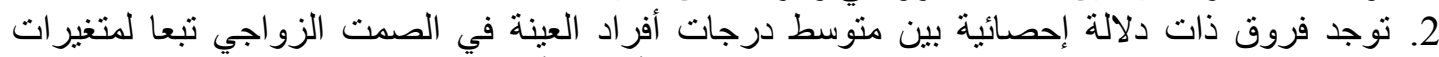

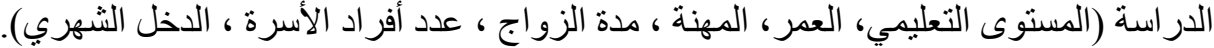

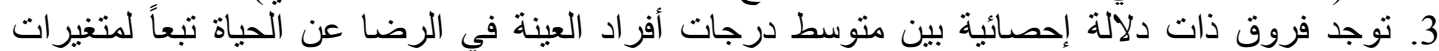

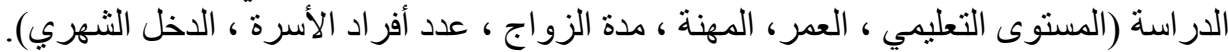

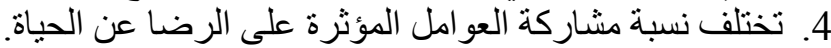
5. تختلف الأوزان النسبية لأولوية محاور الرونة الرضا عن الحياة.

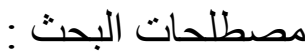

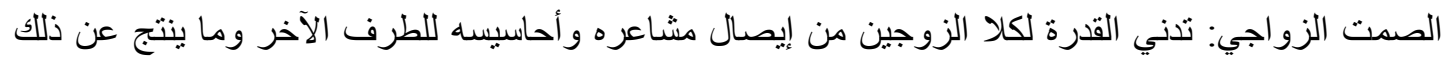

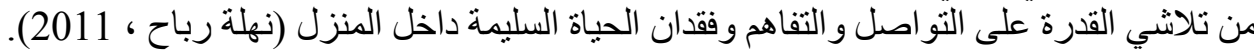

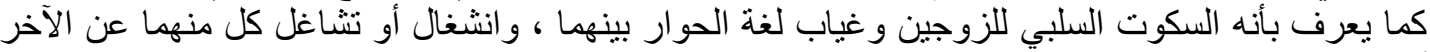

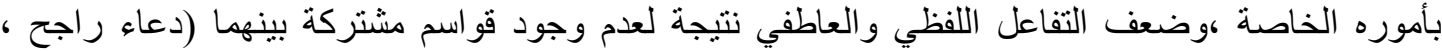
. (2011

الرضا عن الحياة: يعرف بأنه شعور الفرد بالفرح و السعادة والراحة والطمأنينة و إقباله على الحياة بحيوية

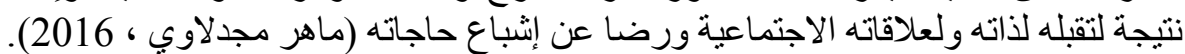

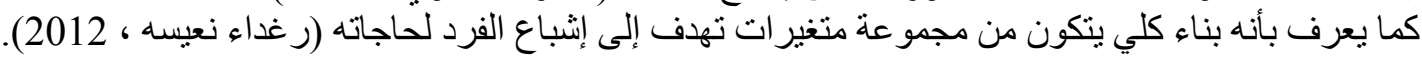




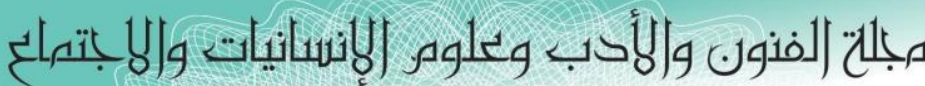

Journal of Arts, Literature, Humanities and Social Sciences

ISSN online: 2414 - 3383

ISSN print: 2616 - 3810

2019 نوفهر

العدد (45)

Volume (45) November 2019

$$
\text { الأسلوب البحثي }
$$

أو لاً: حدود البحث: :

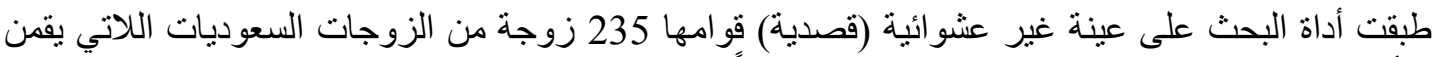

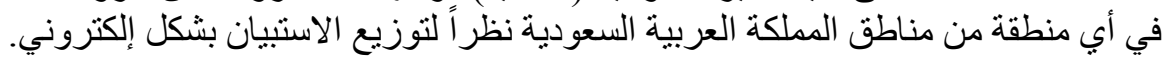

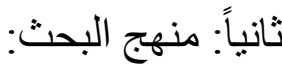

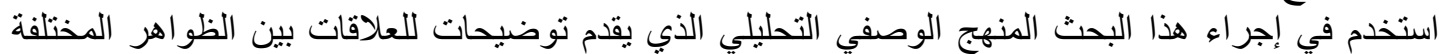

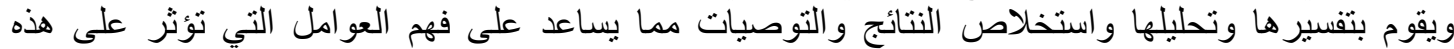
الظواهر (ذوقان عبيدات وآخرون ، 2016).

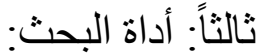

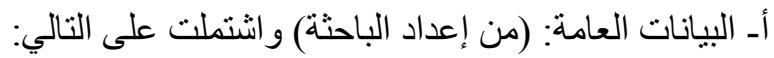

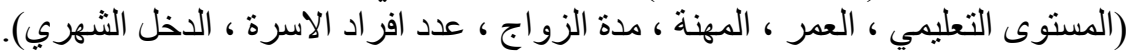

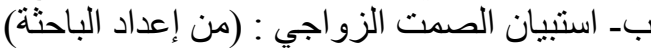

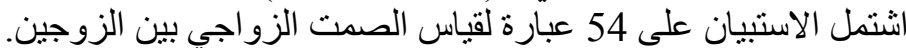

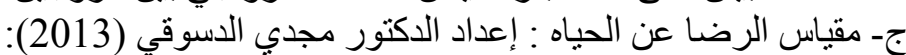
أشتمل الكقياس على 34 عبارة مقسمة الى ست محأور وهي على النى النحو التالي: 1 - 1 - محور السعادة: ويتكون من (8) عبار ات تقبس مدى تمتع الفرد بالسعادة و الثعور بالرضا والارتياح عن ظروفه الحياتية . 20 - 20 - محور الاجتماعية: ويتكون من(5) عبار ات تقيس اتصاف سلوك الفرد بالتسامح و المرح ، و الميل الى الضحك وتبادل الدعابة وتقبل

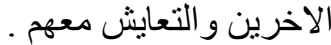

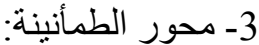

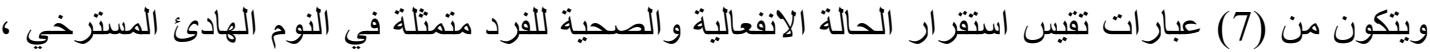

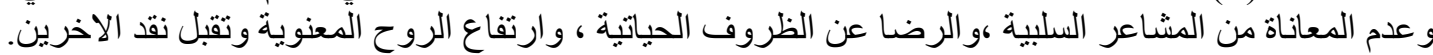

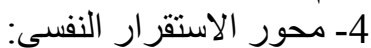
ويتكون من (4) عبار ات تقيس الرضا عن النفس ، والثعور بالبهجة و التفاؤل تجاه المستقبل. 5- 5 محور التقدير الاجتماعي: ويتكون من (6) عبار ات تقيس الثقة في القدر ات و الامكانيات و الاعجاب تجاه السلوك الاجنماعي

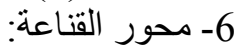
وينكون من (4) عبار ات تقيس رضا الفرد وقناعته بما وصل اليه وبمستوى الحياة أو المعيشة الذي يعيش فيه.

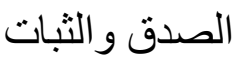

$$
\text { أو لاً: استبيان الصدت الزواجي : }
$$

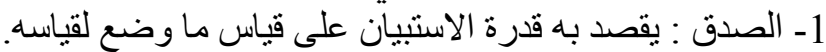

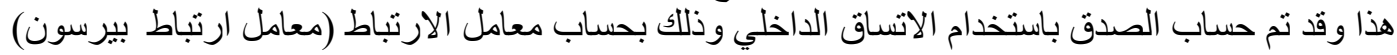

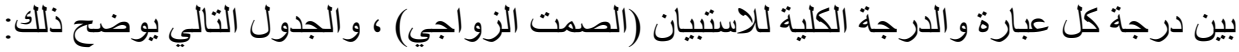




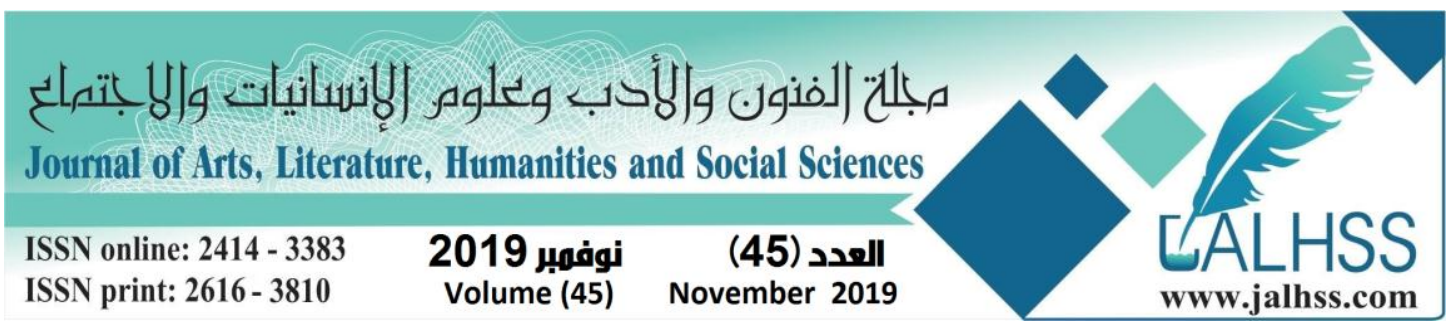

جدول (1) قيم معاملات الارتباط بين درجة كل عبارة والدرجة الكلية للاستبيان (الصمت الزواجي)

\begin{tabular}{|c|c|c|c|c|c|}
\hline الدلالة & الارتباط & 5 & الدلالة & الارتباط & 5 \\
\hline 0.01 & 0.872 & 28 & 0.01 & 0.733 & $\overline{11}$ \\
\hline 0.05 & 0.602 & 29 & 0.01 & 0.824 & 2 \\
\hline 0.05 & 0.628 & 30 & 0.01 & 0.919 & 3 \\
\hline 0.01 & 0.906 & 31 & 0.01 & 0.709 & 4 \\
\hline 0.01 & 0.784 & 32 & 0.01 & 0.851 & 5 \\
\hline 0.01 & 0.848 & 33 & 0.05 & 0.634 & 6 \\
\hline 0.01 & 0.755 & 34 & 0.01 & 0.766 & 7 \\
\hline 0.01 & 0.796 & 35 & 0.01 & 0.885 & 8 \\
\hline 0.01 & 0.738 & 36 & 0.01 & 0.947 & 9 \\
\hline 0.01 & 0.881 & 37 & 0.01 & 0.774 & 10 \\
\hline 0.01 & 0.944 & 38 & 0.01 & 0.865 & 11 \\
\hline 0.01 & 0.702 & 39 & 0.01 & 0.923 & 12 \\
\hline 0.05 & 0.640 & 40 & 0.01 & 0.716 & 13 \\
\hline 0.01 & 0.821 & 41 & 0.05 & 0.613 & 14 \\
\hline 0.01 & 0.799 & 42 & 0.01 & 0.838 & 15 \\
\hline 0.01 & 0.915 & 43 & 0.01 & 0.895 & 16 \\
\hline 0.01 & 0.764 & 44 & 0.01 & 0.936 & 17 \\
\hline 0.01 & 0.858 & 45 & 0.01 & 0.801 & 18 \\
\hline 0.05 & 0.639 & 46 & 0.01 & 0.749 & 19 \\
\hline 0.01 & 0.743 & 47 & 0.01 & 0.817 & 20 \\
\hline 0.01 & 0.862 & 48 & 0.01 & 0.723 & 21 \\
\hline 0.01 & 0.777 & 49 & 0.05 & 0.601 & 22 \\
\hline 0.01 & 0.927 & 50 & 0.01 & 0.896 & 23 \\
\hline 0.01 & 0.803 & 51 & 0.01 & 0.757 & 24 \\
\hline 0.01 & 0.714 & 52 & 0.01 & 0.842 & 25 \\
\hline 0.05 & 0.622 & 53 & 0.01 & 0.728 & 26 \\
\hline 0.01 & 0.839 & 54 & 0.01 & 0.903 & 27 \\
\hline
\end{tabular}

يتضح من الجدول أن معاملات الارتباط كلها دالة عند مستوى (0.01 - 0.05) لاقترابها من الواحد الصحيح مما يدل على صدق وتجانس عبار ات الاستبيان .

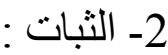

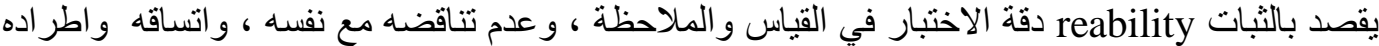

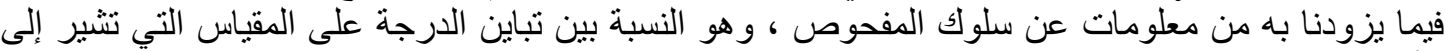

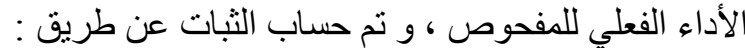

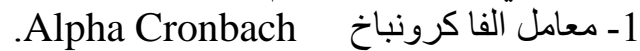
2- 2- طريقة التجزئة النصفية

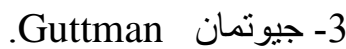




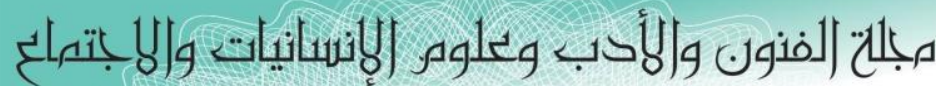
Journal of Arts, Literature, Humanities and Social Sciences

ISSN online: 2414 - 3383

ISSN print: 2616 - 3810

2019 نوفر

Volume (45)
العدد (45)

November 2019

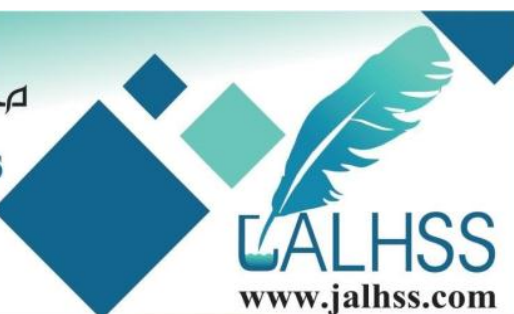

www.jalhss.com

جدول (2) قيم معامل الثبات لاستبيان الصمت الزواجي

\begin{tabular}{|c|c|c|c|}
\hline جيوتما & التجزئة النصفية & معامل & \\
\hline 0.768 & $0.826-0.751$ & 0.789 & ثنات استبيان الصمت الزواجي \\
\hline
\end{tabular}

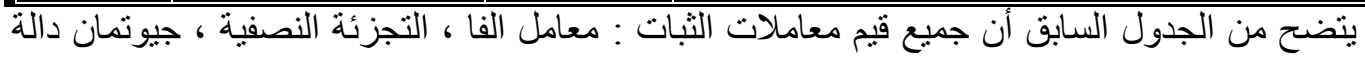
عند مستوى 0.01 مما يدل على ثبات الاستبيان .

$$
\text { ثانياً: استبيان الرضا عن الحياة : }
$$

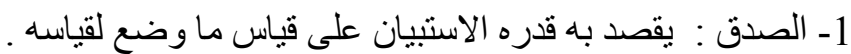

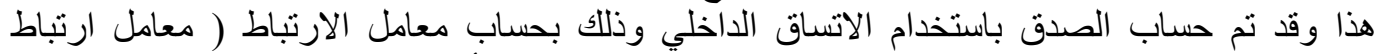

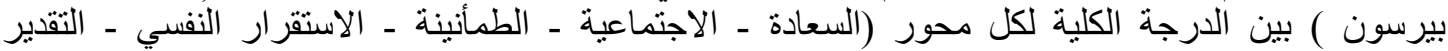

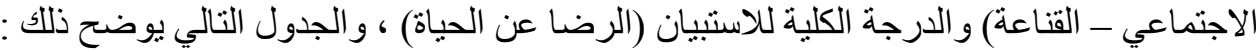

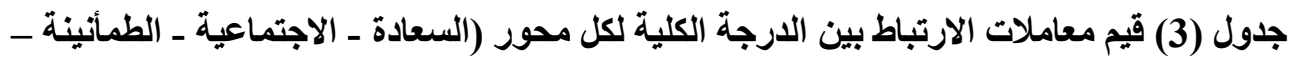

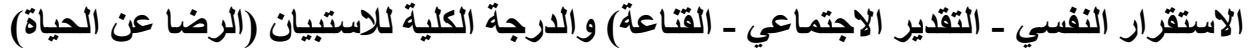

\begin{tabular}{|c|c|c|}
\hline 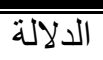 & الارتباط & المحاور \\
\hline 0.01 & 0.814 & المحور الأول : السعادة \\
\hline 0.01 & 0.781 & المحور الثاني : الاجتماعية \\
\hline 0.01 & 0.875 & المحور الثالث : الطمأنينة \\
\hline 0.01 & 0.937 & المحور الر ابع : الاستقرار النفسي \\
\hline 0.01 & 0.763 & المحور الخامس : التقدير الاجتماعي \\
\hline 0.01 & 0.855 & المحور السادس : القناعة \\
\hline
\end{tabular}

يتضح من الجدول أن معاملات الارنباط كلها دالة عند مستوى ( 0.01 ) لاقتر ابها من الواحد الصحيح مما

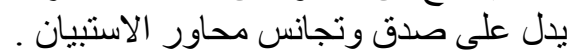

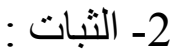

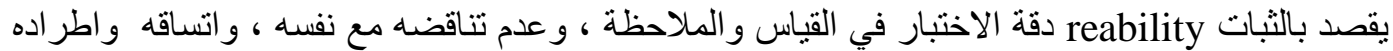

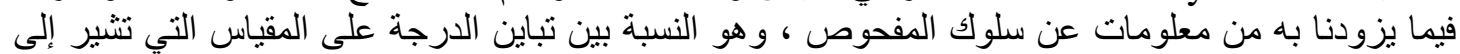

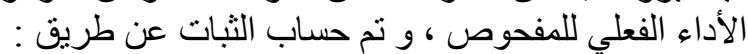

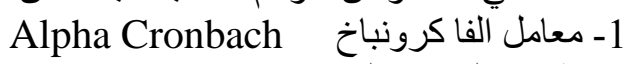

2- طريقة التجزئة النصفية 3uttman 3يونمان

جدول (4) قيم معامل الثبات لمحاور استبيان الرضا عن الحياة

\begin{tabular}{|c|c|c|c|}
\hline جيوتما & التجزئة النصفية & معامل & المحاور \\
\hline 0.732 & $0.792-0.728$ & 0.755 & المحور الأول : السعادة \\
\hline 0.826 & $0.886-0.812$ & 0.843 & المحور الثاني : الاجتماعية \\
\hline 0.908 & $0.958-0.891$ & 0.920 & المحور الثالث : الطمأنينة \\
\hline
\end{tabular}




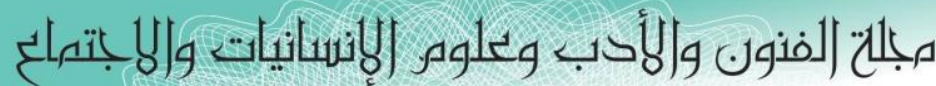

Journal of Arts, Literature, Humanities and Social Sciences

ISSN online: 2414 - $3383 \quad$ (45)

ISSN print: 2616 - 3810

Volume (45) November 2019

\begin{tabular}{|c|c|c|c|}
\hline 0.700 & $0.752-0.689$ & 0.716 & المحور الرابع : الاستقرار النفسي \\
\hline 0.784 & $0.841-0.777$ & 0.803 & المحور الخامس : التقدير الاجتماعي \\
\hline 0.899 & $0.952-0.881$ & 0.912 & المحور السادس : القناعة \\
\hline 0.845 & $0.901-0.831$ & 0.864 & ثبات استبيان الرضا عن الحياة ككل \\
\hline
\end{tabular}

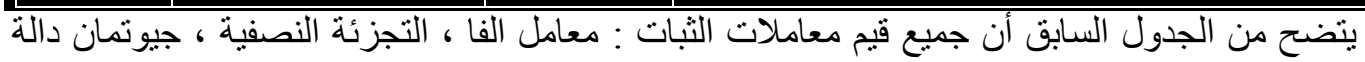

استمارة البيانات العامة

جدول (5) توزيع أفراد عينة البحث تبعا لمتغير المستوى التعليمي

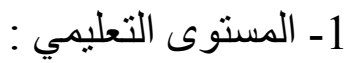

\begin{tabular}{|c|c|c|}
\hline النسبة\%\% & 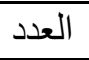 & المستوى التعليمي \\
\hline$\% 8.9$ & 21 & الثهادة الابتدائية أو أقل \\
\hline$\% 18.7$ & 44 & الشهادة المتوسطة \\
\hline$\% 30.2$ & 71 & الثهادة الثانوية /الدبلوم \\
\hline$\% 36.2$ & 85 & الشهادة الجامعية \\
\hline$\% 5.9$ & 14 & أعلى من الجامعي "ماجستير ، دكتور اه" \\
\hline$\% 100$ & 235 & المجموع \\
\hline
\end{tabular}

يتضح من جدول (5) والثكل البياني (1) أن 85 من أفراد عينة البحث حاصلات على الثهادة الجامعية

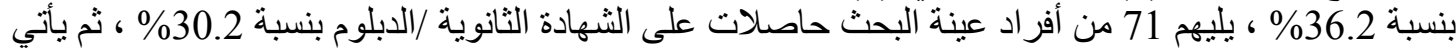

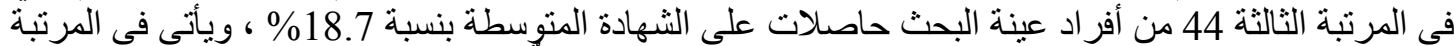

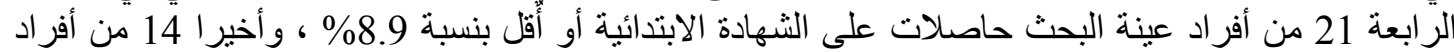
عينة البحث حاصلات على درجات علمية أعلى من المؤهل الجامعي (الماجستير ، الدكتور اه) بنسبة 5.9 5.

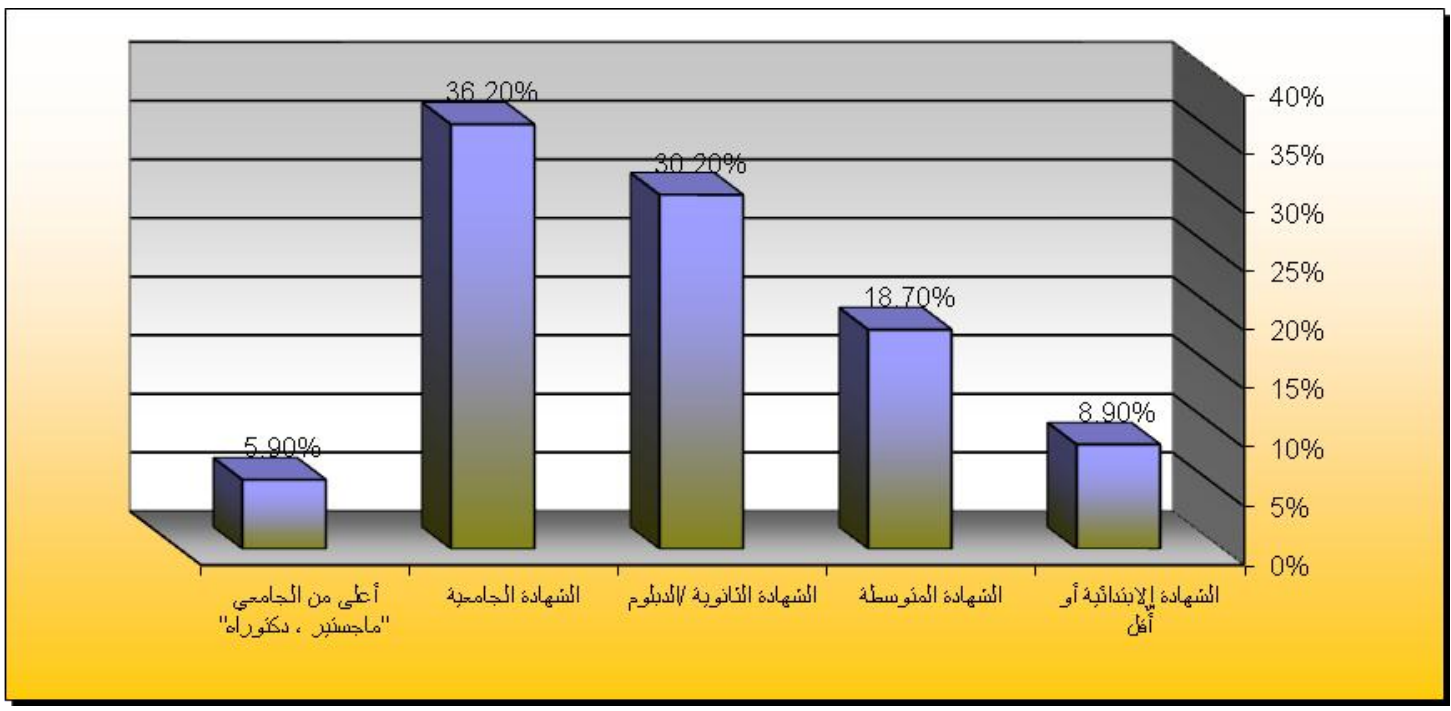

شكل (1) يوضح توزيع أفراد عينة البحث تبعا لمتغير المستوى التعليمي 


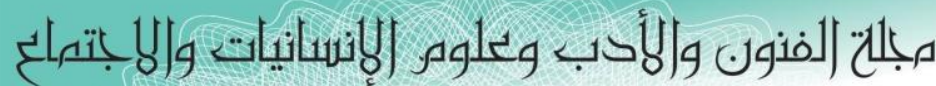

Journal of Arts, Literature, Humanities and Social Sciences

ISSN online: 2414 - $3383 \quad$ (45)

ISSN print: 2616 - 3810

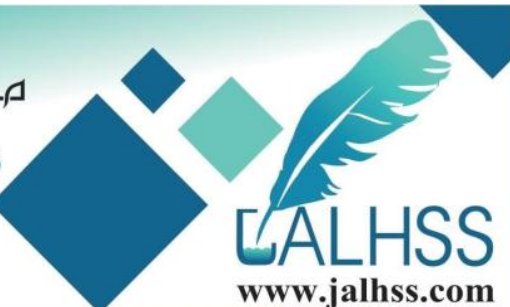

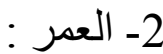

جدول (6) توزيع أفراد عينة البحث تبعا لمتفير العمر

\begin{tabular}{|c|c|c|}
\hline 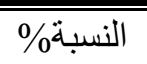 & العدد & 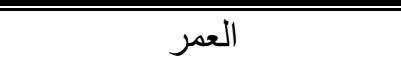 \\
\hline$\% 33.6$ & 79 & أقل من 35 سنة \\
\hline$\% 42.9$ & 101 & من 35 سنة لأقل من 45 سنة \\
\hline$\% 23.4$ & 55 & من 45 سنة فأكثر \\
\hline$\% 100$ & 235 & المجموع \\
\hline
\end{tabular}

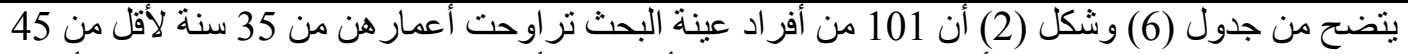

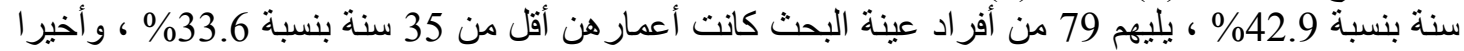
55 من أفر اد عينة البحث كانت أعمار هن من 45 سنة فأكثر بنسبة 23.4 \%

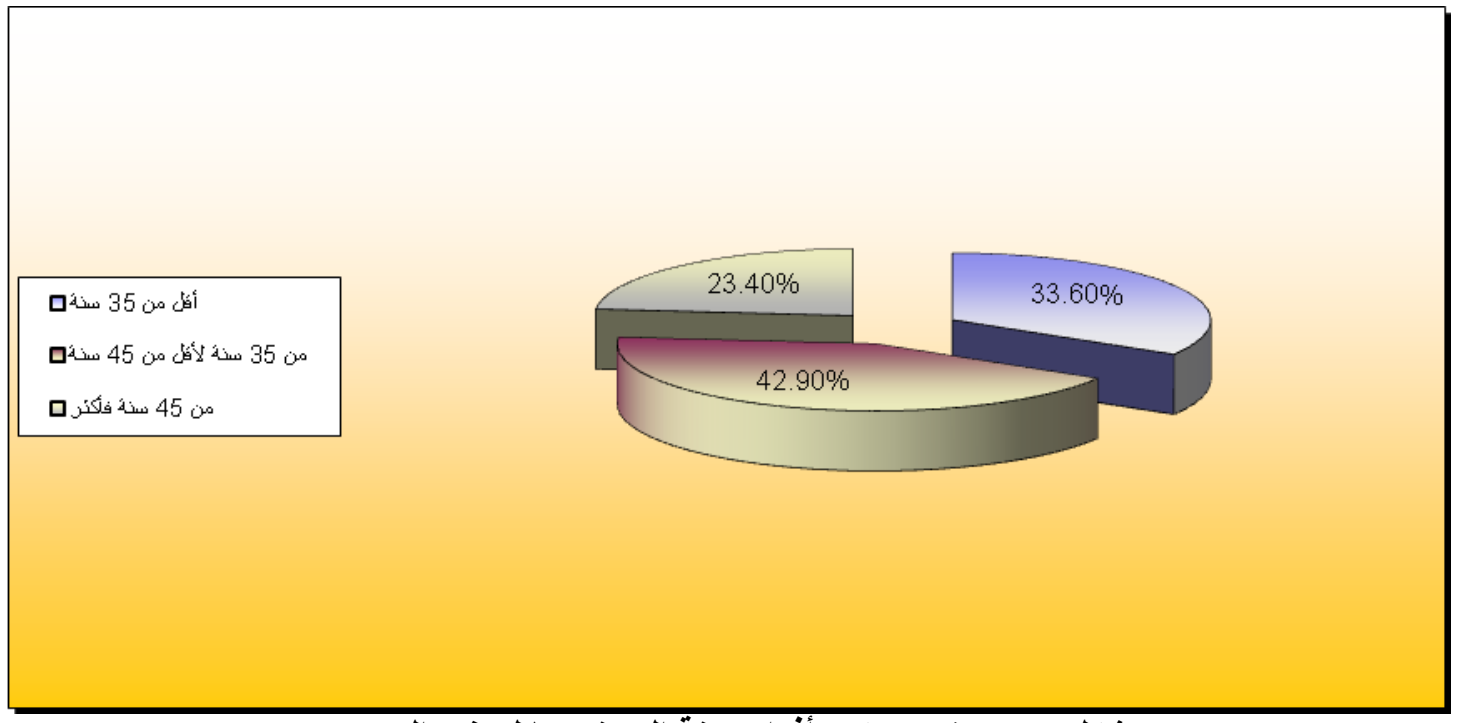

شكل (2) يوضح توزيع أفراد عينة البحث تبعا لمتغير العمر

جدول (7) توزيع أفراد عينة البحث تبعا لمتغير المهنة

\begin{tabular}{|c|c|c|}
\hline النسبة\%\% & العدد ا ل العد & المهنة \\
\hline$\% 27.7$ & 65 & وظيفة حكومية \\
\hline$\% 20.4$ & 48 & قطاع خاص \\
\hline$\% 13.6$ & 32 & أعمال حرة \\
\hline$\% 38.3$ & 90 & لا تعمل / متقاعدة \\
\hline$\%$ \%100 & 235 & المجموع \\
\hline
\end{tabular}

يتضح من جدول (7) و الثكل البياني (3) أن 90 من أفر اد عينة البحث غير عاملات / منقاعدات بنسبة

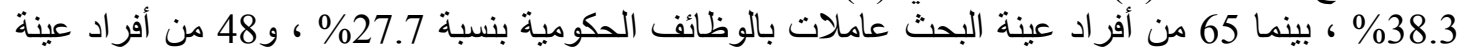

البحث عاملات بالقطاع الخاص بنسبة 20.4\% ، 
مبلحت (لفنون والأدب وعلوه الإنسانيات و|لهابتهالغ Journal of Arts, Literature, Humanities and Social Sciences

ISSN online: 2414 - $3383 \quad$ (45)

ISSN print: 2616 - 3810

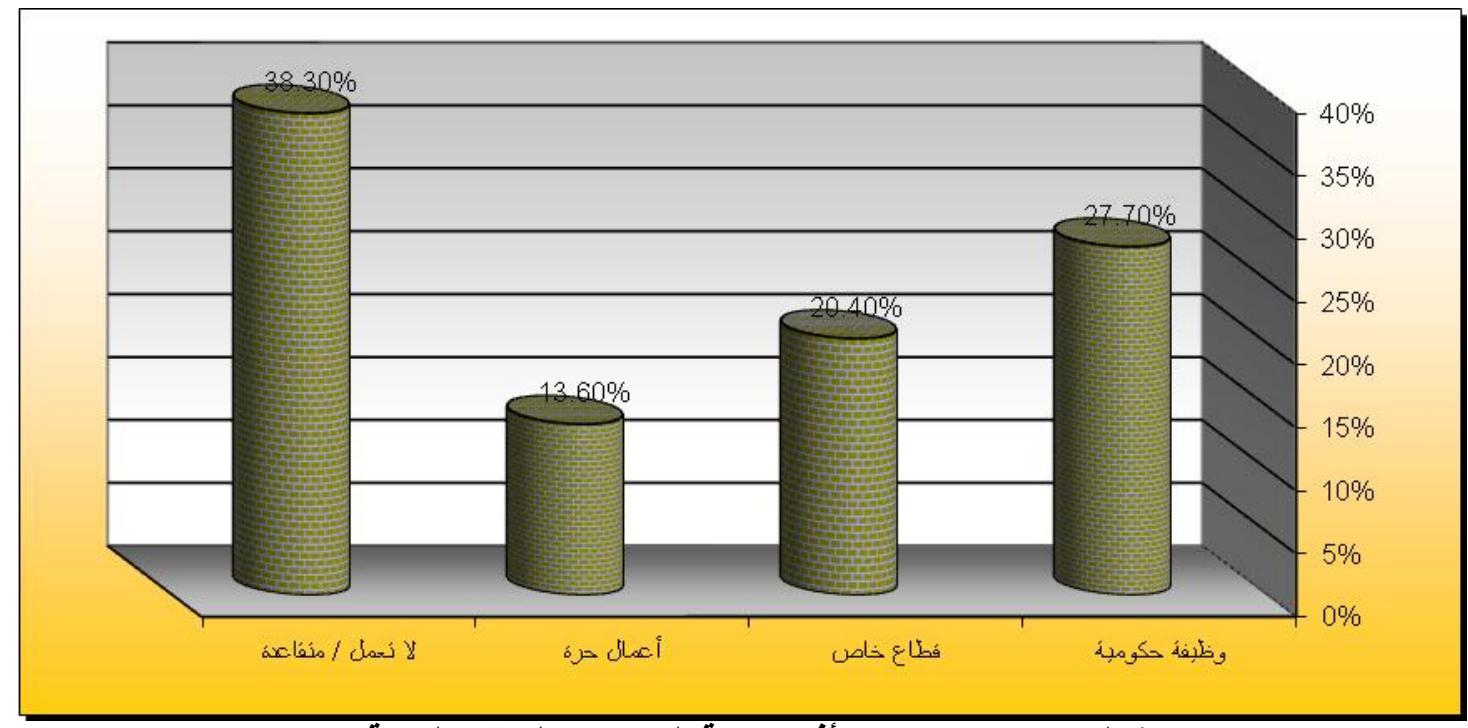

شُكل (3) يوضح توزيع أفراد عينة البحث تبعا لمتفير المهنة

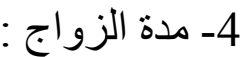

جدول (8) توزيع أفراد عينة البحث تبعا لمتغير مدة الزواج

\begin{tabular}{|c|c|c|}
\hline النسبة\%\% & العدد & مدة الزواج \\
\hline$\% 21.7$ & 51 & أقل من 10 سنوات \\
\hline$\% 47.7$ & 112 & من 10 سنو ات إلي أقل من 20 سنة \\
\hline$\% 30.6$ & 72 & من 20 سنة فأكثر \\
\hline$\% 100$ & 235 & المجموع \\
\hline
\end{tabular}

يتضح من جدول (8) وشكل (4) أن 112 من أفر اد عينة البحث تراوحت مدة زو اجهن من 10 سنو سنوات إلي أقلى

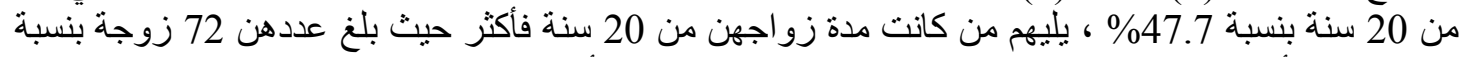
30.6\% ، و أخيرا كان عدد الزوجات اللاتي كانت مدة زواجهن أقل من 10 سنوات حيث بلغن "51" زوجة عندة

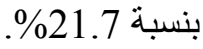

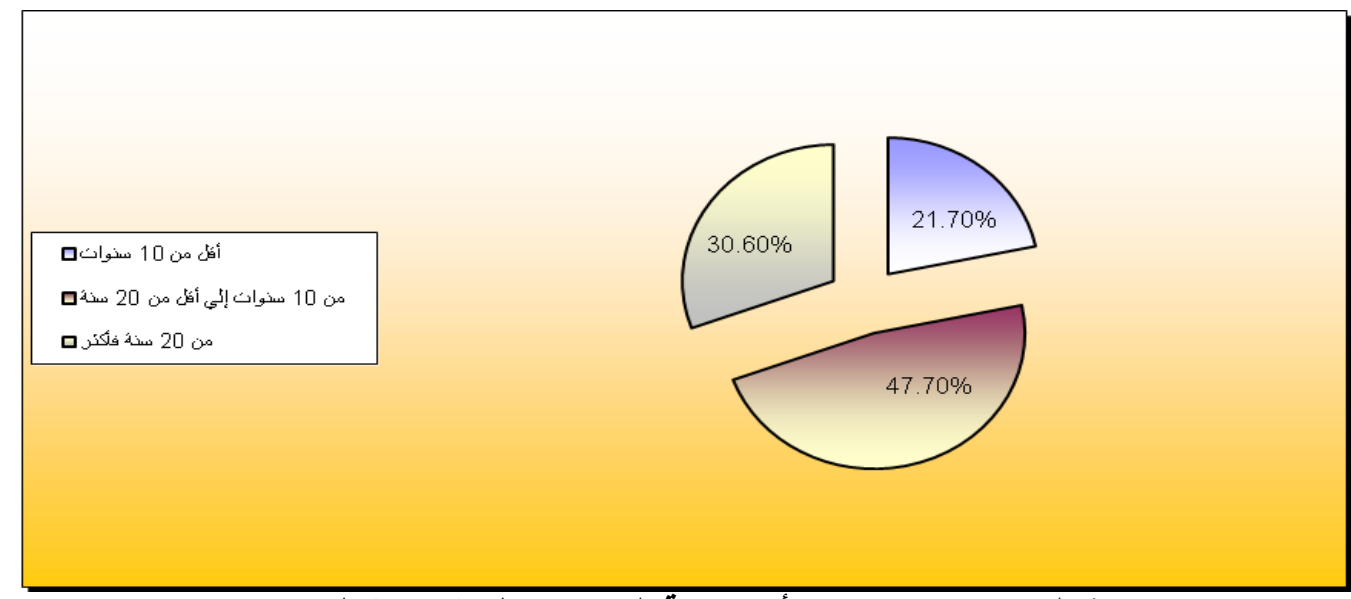

شكل (4) يوضح توزيع أسر عينة البحث تبعا لمتغير مدة الزواج 


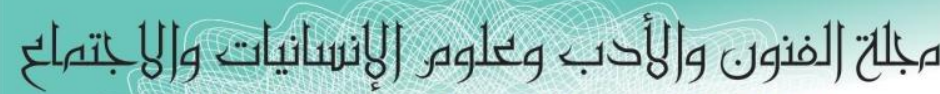
Journal of Arts, Literature, Humanities and Social Sciences

ISSN online: 2414 - $3383 \quad$ العدد (45)

ISSN print: 2616 - 3810

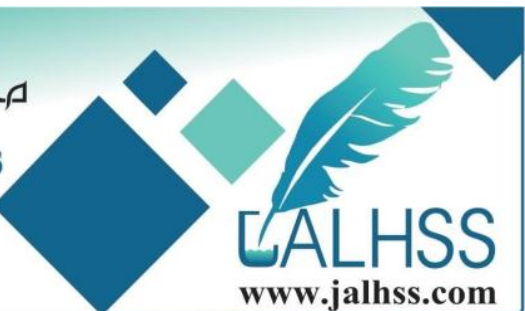

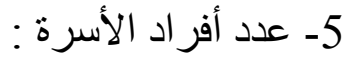

جدول (9) توزيع عينة البحث تبعاً لعدد أفراد الأسرة

\begin{tabular}{|c|c|c|}
\hline النسبة\%\% & العدد & عدد أفراد الأسرة \\
\hline$\% 33.2$ & 78 & أقلّ من 5 أفر اد \\
\hline$\% 42.1$ & 99 & من 5 أفر اد إلي 7 أفر اد \\
\hline$\% 24.7$ & 58 & من 8 أفراد فأكثر \\
\hline \%100 & 235 & المجموع \\
\hline
\end{tabular}

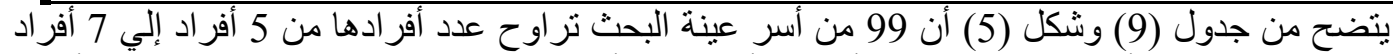

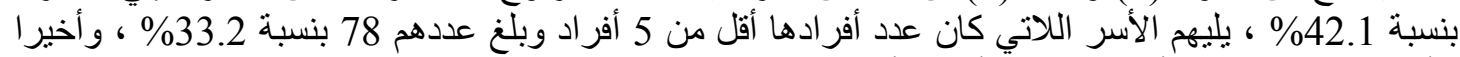

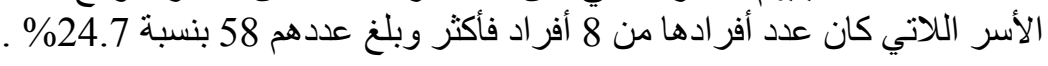

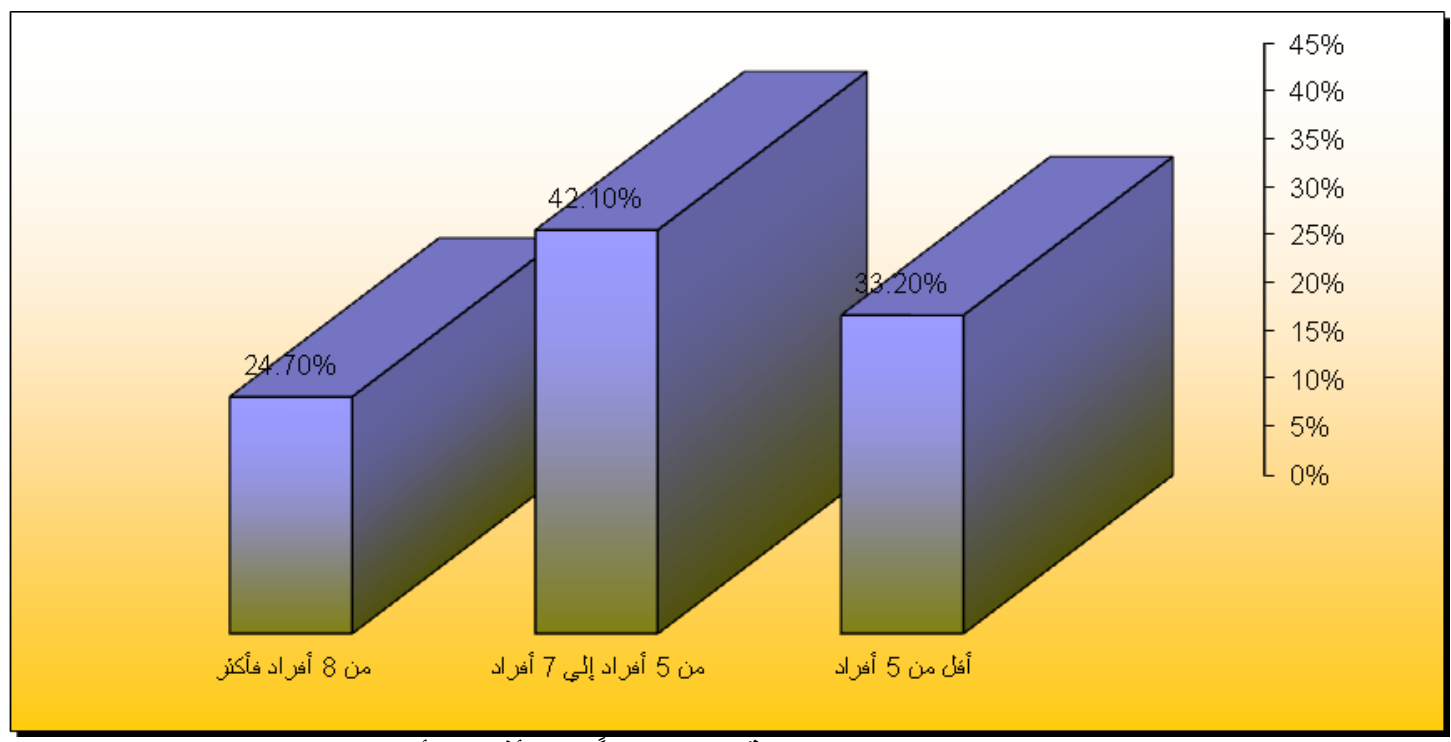

شكل (5) يوضح توزيع عينة البحثُ تبعاً لعدد أفراد الأسرة

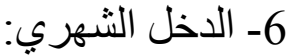

جدول (10) توزيع أفراد عينة البحث وفقا لفئات الاخل الشهري

\begin{tabular}{|c|c|c|}
\hline النسبة\%\% & العدد & الدخل الثشري \\
\hline$\% 11.1$ & 26 & أقل من 3000 ربال \\
\hline$\% 17.9$ & 42 & من 3000 ربال إلى أقل من 6000 ربإل \\
\hline$\% 24.3$ & 57 & من 6000 ربال إلى أقل من 9000 ربال \\
\hline$\% 34.4$ & 81 & من 9000 ربال إلى أقل من 12000 ربال \\
\hline$\% 12.3$ & 29 & من 12000 ربال فأكثر \\
\hline$\% 100$ & 235 & المجموع \\
\hline
\end{tabular}




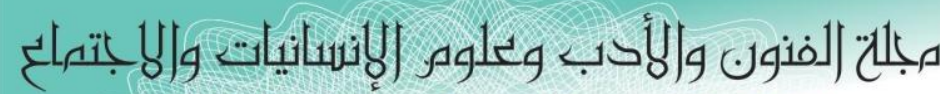
Journal of Arts, Literature, Humanities and Social Sciences

$\begin{array}{lcc}\text { ISSN online: } 2414-3383 & \begin{array}{c}2019 \\ \text { Volume (45) }\end{array} \\ \text { ISSN print: } 2616-3810 & \begin{array}{c}\text { (45) } \\ \text { November } 2019\end{array}\end{array}$

يتضح من جدول (10) و الثنكل البياني (6) أن أكبر فئات الدخل الثهري لأفر اد عبنة البحث كان في الفئة

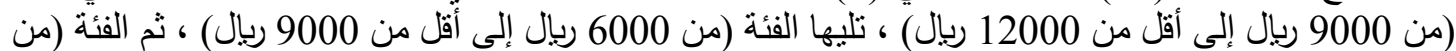
3000 ربال إلى أقل من 6000 ربال) ، فقد بلغت نسبتهم على التو الي (34.4\% ؛

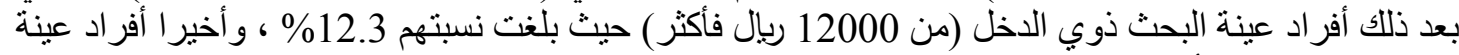
البحث ذوي الدخل (أقل من 3000 ربال) حيث بلغت نسبتهم 11.1\% .

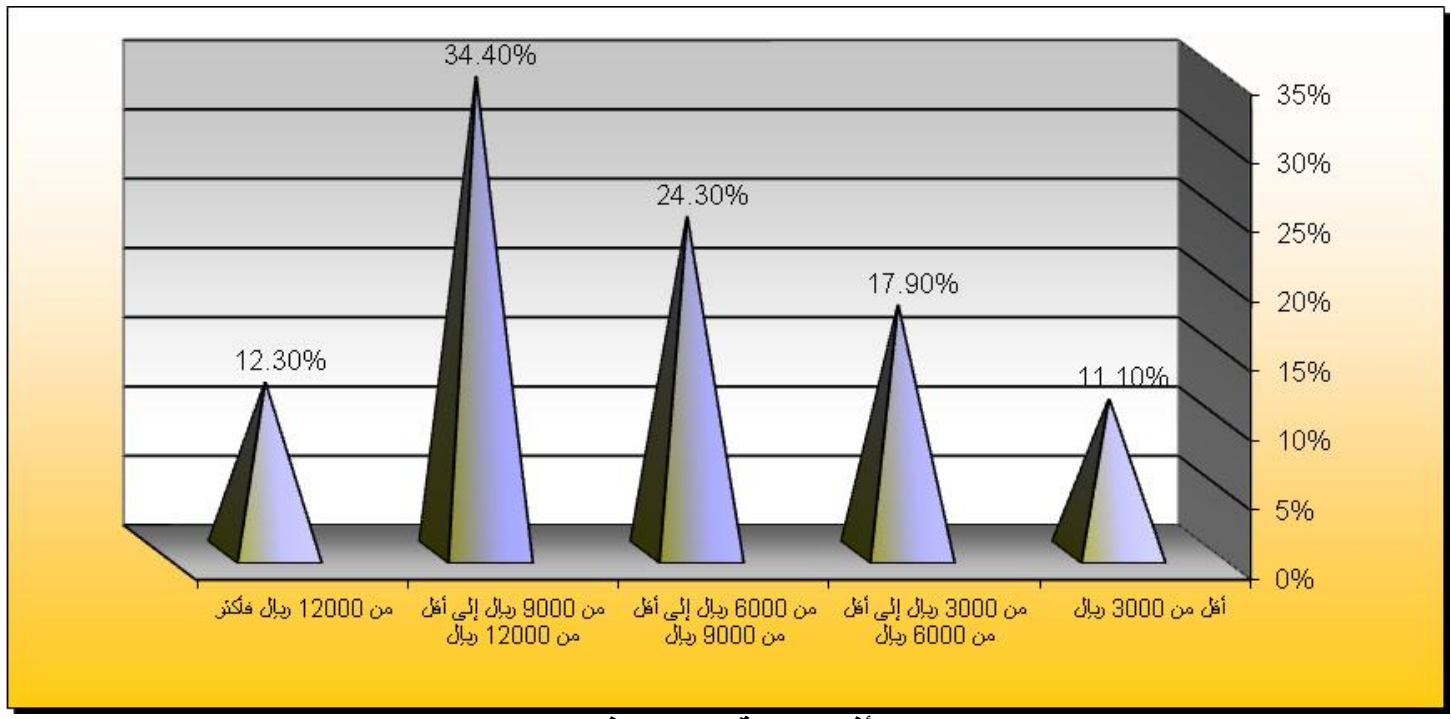

شكل (6) يوضح توزيع أفراد عينة البحث وفقا لفئات الاخل الشهري

النتائج

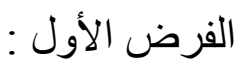
توجد علاقة ارتباطية بين الصمت الزون الزو اجي و الرضا عن الحياة

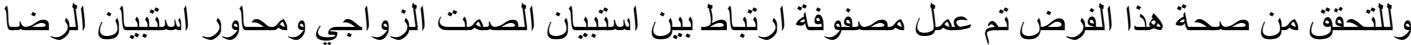
عن الحياة و الجدول التالي يوضح فيم المرضم معاملات الارتباط :

جدول (11) مصفوفة الارتباط بين استبيان الصمت الزواجي ومحاور استبيان الرضا عن الحياة

\begin{tabular}{|c|c|c|c|c|c|c|c|}
\hline عن الرياة & القناعة & الاجتماعي التقدير & الاستقر ار & الطمأنينة & الاجتماء & السعادة & \\
\hline$* *-$ & $* *-$ & $\begin{array}{c}- \\
* * 0.796\end{array}$ & $*{ }^{*}-\overline{9}$ & $\begin{array}{c}- \\
* * 0.824\end{array}$ & 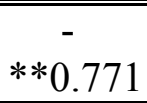 & $\begin{array}{c} \\
* * 0.895\end{array}$ & الزواجي \\
\hline
\end{tabular}

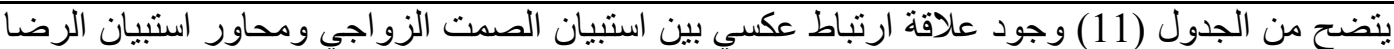

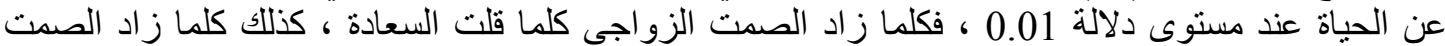

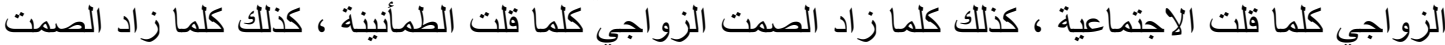

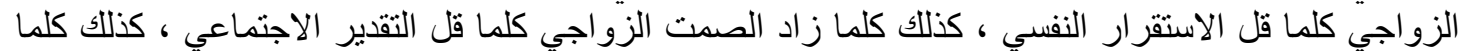

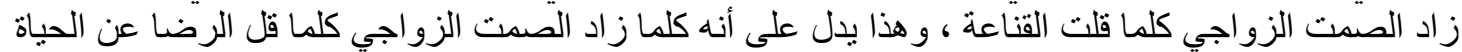

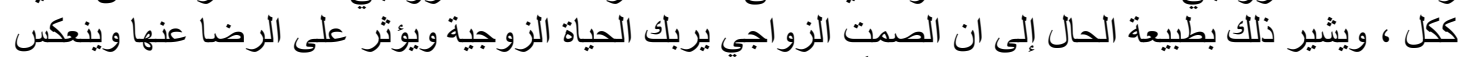

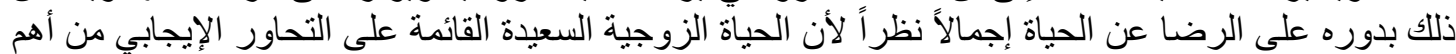

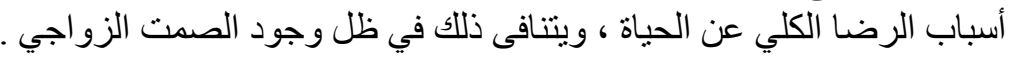




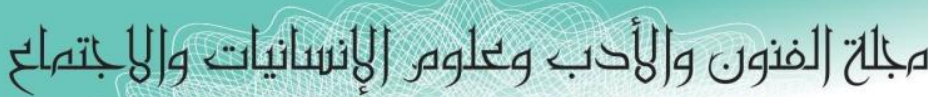
Journal of Arts, Literature, Humanities and Social Sciences

ISSN online: 2414 - 3383

ISSN print: 2616 - 3810

2019 نوفر Volume (45)
العدد (45) November 2019

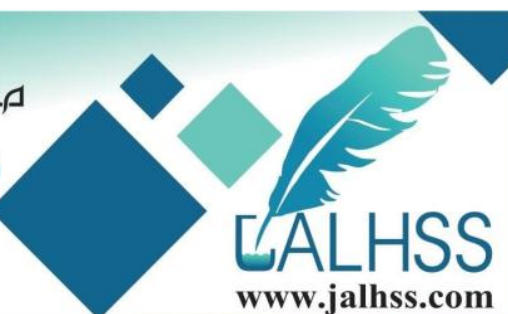

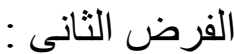

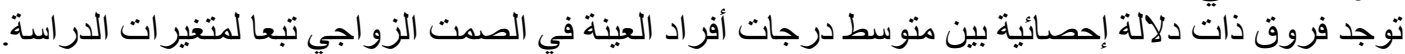

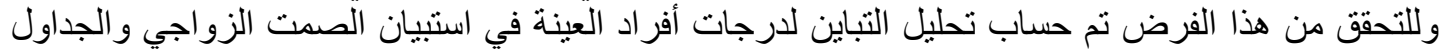

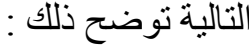

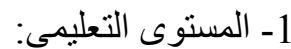

جدول (12) تحليل التباين لارجات أفراد العينة في الصمت الزواجي تبعا لمتغير المستوي التعليمي

\begin{tabular}{|c|c|c|c|c|c|}
\hline 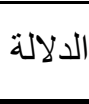 & قفيمة ( ق فيم) & الحرية & متوسط المربعات & مجموع المربعات & المستوي التعليمي \\
\hline \multirow{2}{*}{ ב } & \multirow[b]{2}{*}{50.755} & 2 & 76657.833 & 153315.666 & بين المجمو عات \\
\hline & & 232 & 1510.347 & 350400.521 & 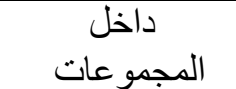 \\
\hline & & 234 & & 503716.187 & المجموع \\
\hline
\end{tabular}

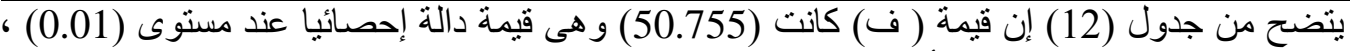

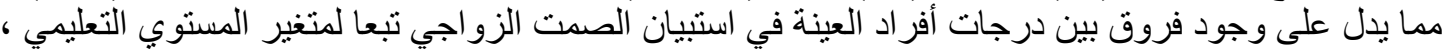

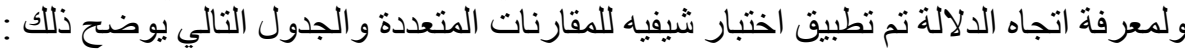

جدول (13) اختبار شيفيه للمقارنات المتعددة

\begin{tabular}{|c|c|c|c|}
\hline 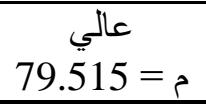 & م= متوسط 118.577 مت & م = منخفض 149.876 & المستوي التعليمي \\
\hline & & - & منخفض \\
\hline & - & **31.299 & متوسط \\
\hline - & **39.062 & $* * 70.361$ & عالي \\
\hline
\end{tabular}

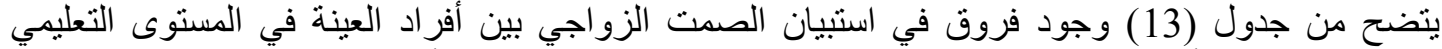

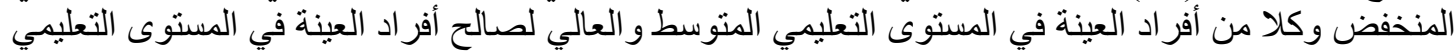

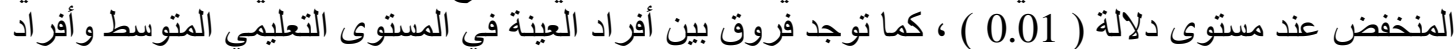

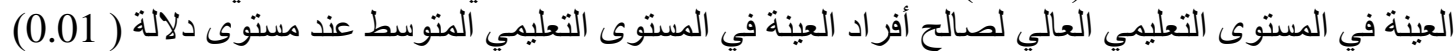

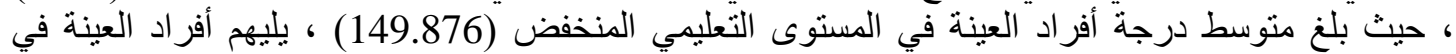

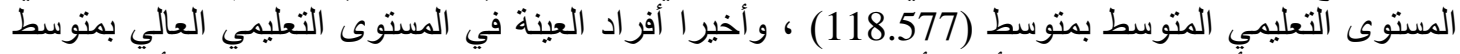

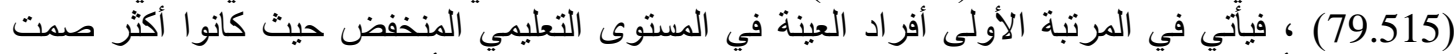

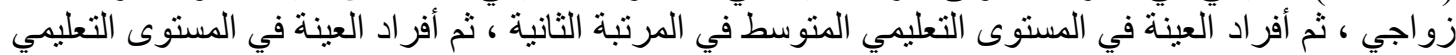

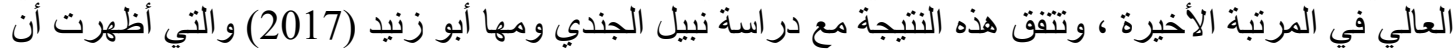

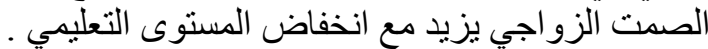




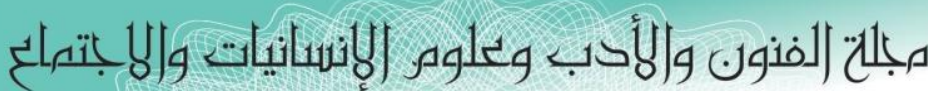
Journal of Arts, Literature, Humanities and Social Sciences

ISSN online: 2414 - 3383

ISSN print: 2616 - 3810

2019 نوفهر

Volume (45)
العدد (45)

November 2019

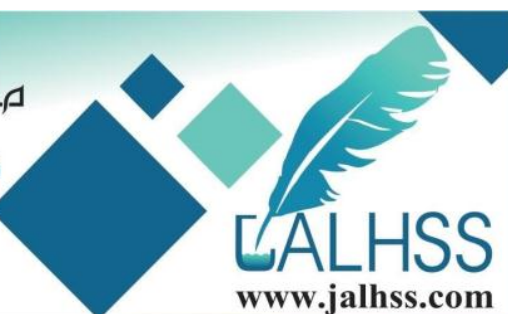

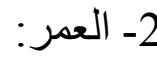

جدول (14) تحليل التباين لارجات أفراد العينة في استبيان الصمت الزواجي تبعا لمتغير العمر

\begin{tabular}{|c|c|c|c|c|c|}
\hline الدلالة الد & قيمة (ف) & درجة & منوسط المربعات & مجموع المربعات & العمر \\
\hline \multirow[t]{3}{*}{ (0.01 دال } & 36.475 & 2 & $\overline{660680.729}$ & 121361.457 & بين المجمو عات \\
\hline & & 232 & 1663.645 & 385965.624 & 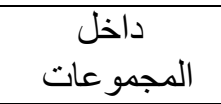 \\
\hline & & 234 & & $\overline{507327.081}$ & المجموع \\
\hline
\end{tabular}

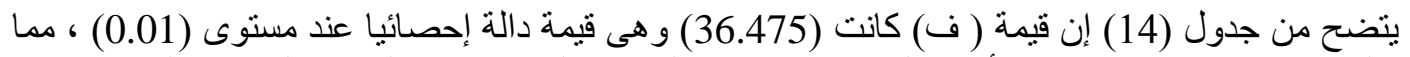

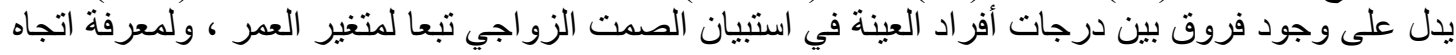

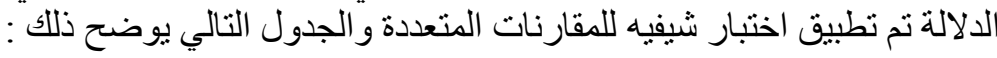

جدول (15) اختبار شيفيه للمقارنات المتعددة

\begin{tabular}{|c|c|c|c|}
\hline من 45 سنة فأكثر & من 35 سنة لأقل من 45 & أقل من 35 سنة 145.202 & 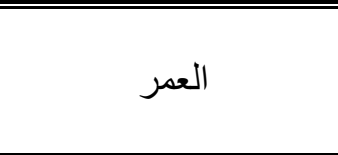 \\
\hline & & - & أقل من 35 سنة \\
\hline & - & $* * 50.717$ & من 35 سنة لأقل من 45 \\
\hline- & $* 3.230$ & $* * 53.947$ & من 45 سنة فأكثر \\
\hline
\end{tabular}

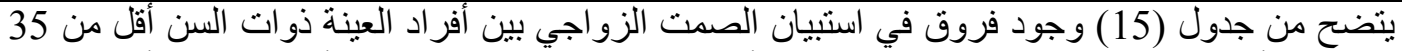

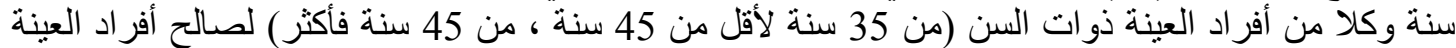

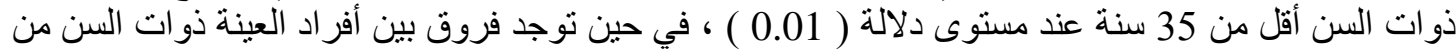

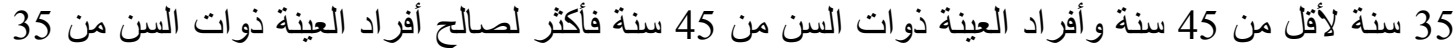

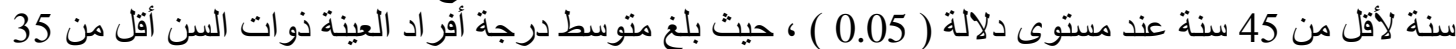

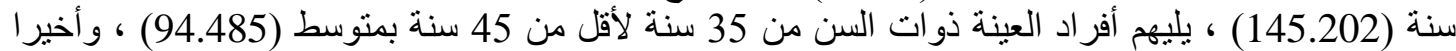

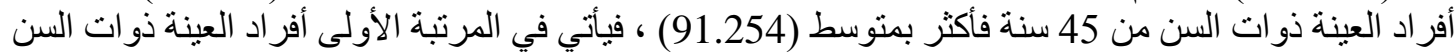

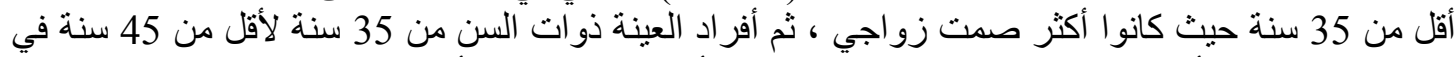

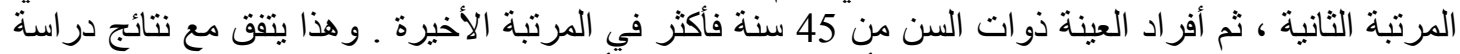

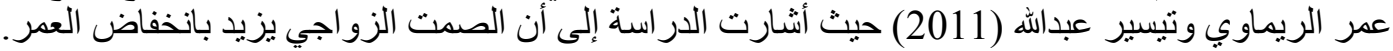

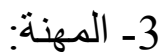

جدول (16) تحليل التباين لدرجات أفراد العينة في الصمت الزواجي تبعا لمتفير المهنة

\begin{tabular}{|c|c|c|c|c|c|}
\hline 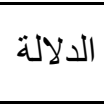 & قيمة (ف) & الحرية & متوسط المربعات & مجموع المربعات & المهنة \\
\hline \multirow{3}{*}{$\begin{array}{r}0.01 \\
\text { دال }\end{array}$} & \multirow{2}{*}{44.937} & 3 & 52636.036 & 157908.108 & بين المجموعات \\
\hline & & 231 & 1171.324 & 270575.790 & داخل المجمو عات \\
\hline & & 234 & & 428483.898 & المجموع \\
\hline
\end{tabular}




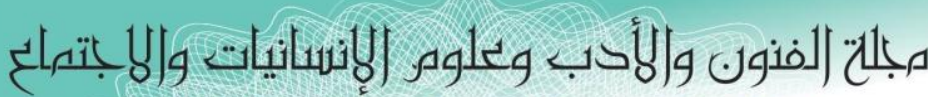
Journal of Arts, Literature, Humanities and Social Sciences

ISSN online: 2414 - 3383

ISSN print: 2616 - 3810

2019 نوفمبر

Volume (45)
العدد (45)

November 2019

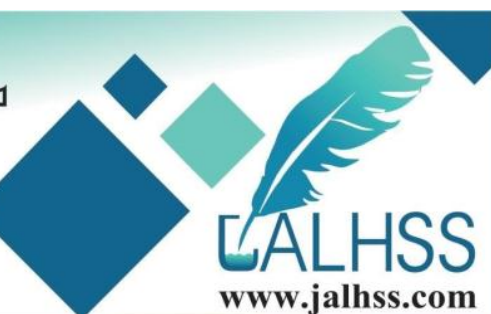

www.jalhss.com

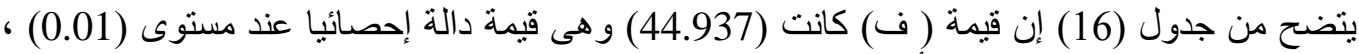

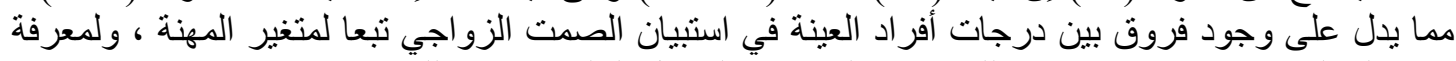

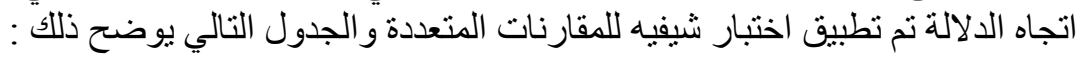

جدول (17) اختبار شيفيه للمقارنات المتعددة

\begin{tabular}{|c|c|c|c|c|}
\hline لا تعمل / متقاعدة & م = أعمال حرة & ق = قطاع خاص & م = وظيفة حكومية & المهنة \\
\hline & & & - & وظيفة حكومية \\
\hline & & - & $* * 31.223$ & قطاع خاص \\
\hline & - & $* * 9.968$ & $* * 41.191$ & أعمال حرة \\
\hline - & $* * 75.246$ & $* * 65.277$ & $* * 34.054$ & لا تعمل / متقاعدة \\
\hline
\end{tabular}

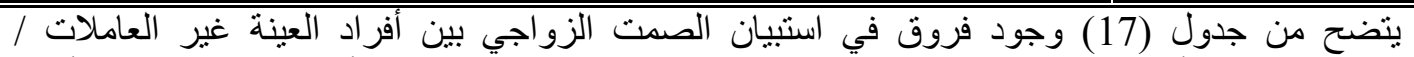

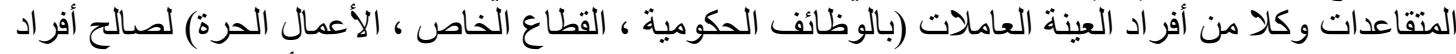

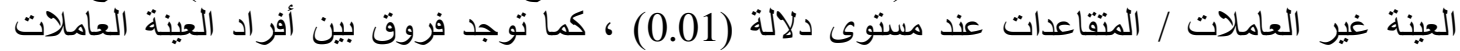

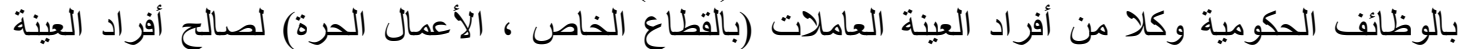

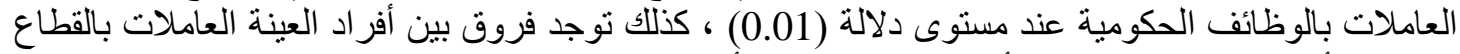

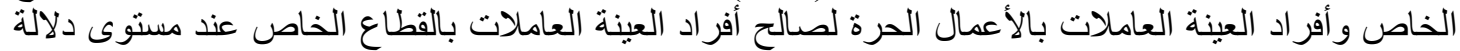

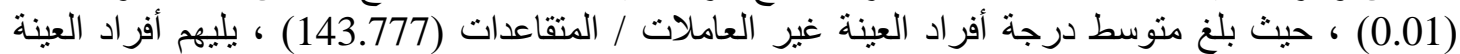

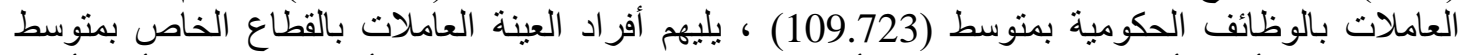

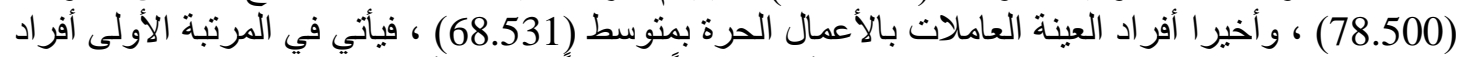

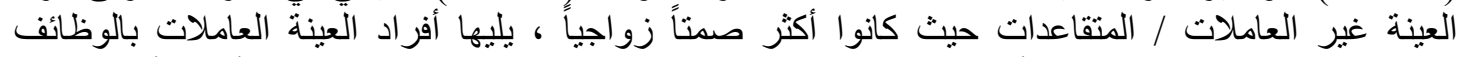

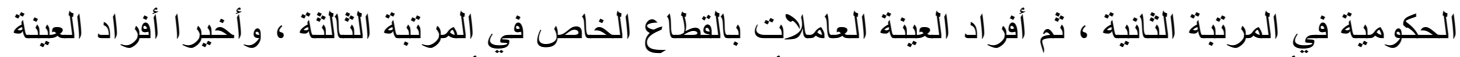

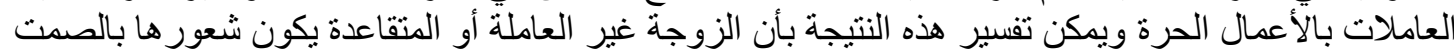

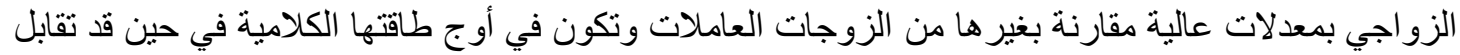
بزوج مستنفذ للطاقة الكلامية.

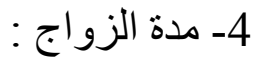

جدول (18) تحليل التباين لارجات أفراد العينة في الصمت الزواجي تبعا لمتغير مدة الزواج

\begin{tabular}{|c|c|c|c|c|c|}
\hline الدلالة الد & قيمة (ف) & الدرجية & متوسط المربعات & مجموع المربعات & مدة الزواج \\
\hline \multirow{3}{*}{$\begin{array}{r}0.01 \\
\text { دال }\end{array}$} & \multirow{2}{*}{54.328} & 2 & 76565.489 & 153130.978 & بين المجمو عات \\
\hline & & 232 & 1409.332 & 326964.920 & داخل المجمو عات \\
\hline & & 234 & & 480095.898 & المجموع \\
\hline
\end{tabular}

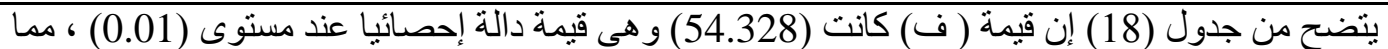

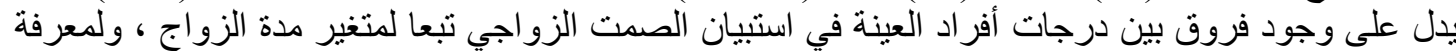
اتجاه الدلالة تم تطبيق اختبار شيفيه للمقارنات المتعددة و الجدول التالي يوضح الزئ ذلك: 


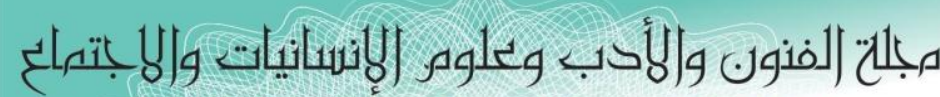
Journal of Arts, Literature, Humanities and Social Sciences

ISSN online: 2414 - 3383

ISSN print: 2616 - 3810

2019 نوف (45)
Volume

العدد (45)

November 2019

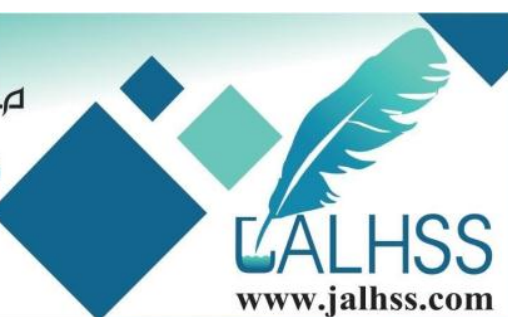

جدول (19) اختبار شيفيه للمقارنات المتعددة

\begin{tabular}{|c|c|c|c|}
\hline من 20 سنة فأكثر & من 10 سنو ات إلى 20 سنة & أقل من 10 سنو ات & مدة الزو اج \\
\hline & & - & أقل من 10 سنو ات \\
\hline & - & $* * 36.819$ & من 10 سنوات إلي أقل من 20 \\
\hline- & $* * 44.608$ & $* * 81.427$ & من 20 سنة فأكثر \\
\hline
\end{tabular}

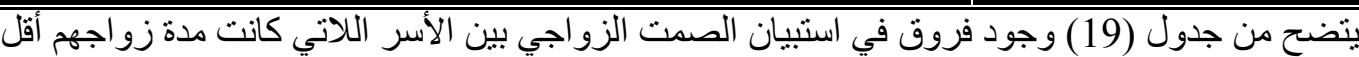

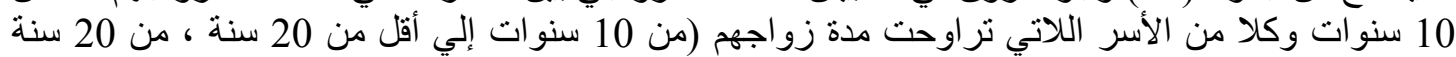

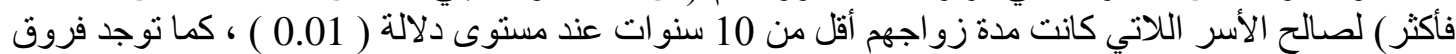

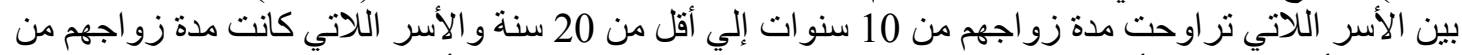

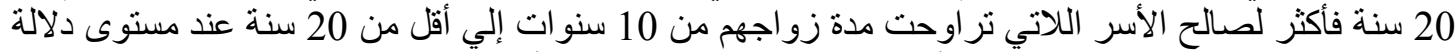

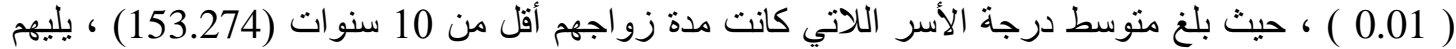

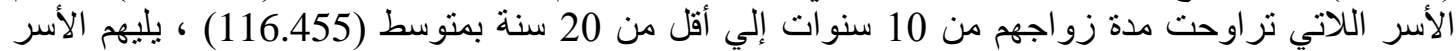

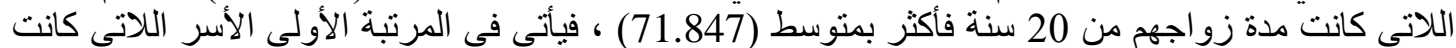

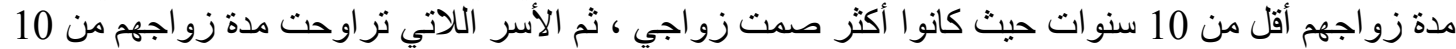

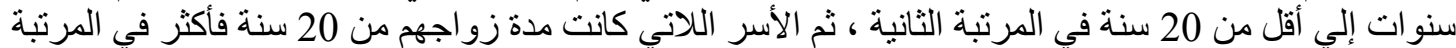

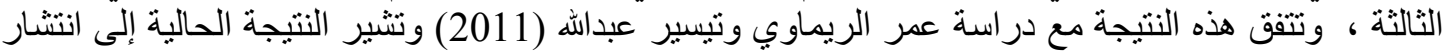

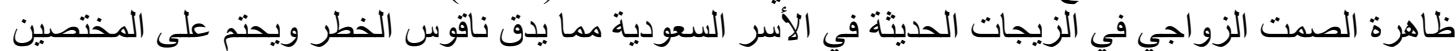

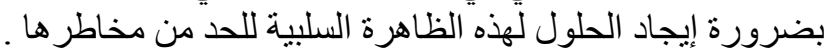

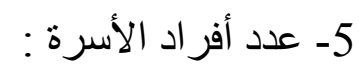

جدول (20) تحليل التباين لارجات أفراد العينة في الصمت الزواجي تبعا لمتغير عدد أفراد الأسرة

\begin{tabular}{|c|c|c|c|c|c|}
\hline الدلالة & قبمة (ف) & الحرية & متوسط المربعات & مجموع المربعات & عدد أفر اد الأسرة \\
\hline \multirow{3}{*}{$\begin{array}{r}0.01 \\
\text { دال }\end{array}$} & \multirow{2}{*}{47.096} & 2 & 81815.330 & 163630.659 & بين المجمو عات \\
\hline & & 232 & 1737.196 & 403029.528 & داخل الدجمو عات \\
\hline & & 234 & & 566660.187 & المجموع \\
\hline
\end{tabular}

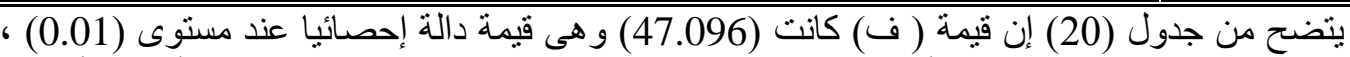

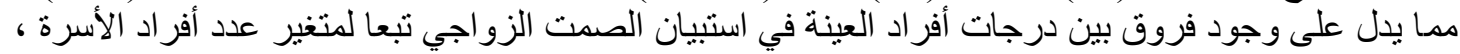

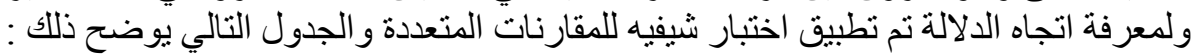

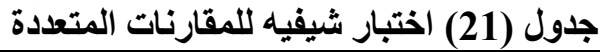

\begin{tabular}{|c|c|c|c|}
\hline من = 8 أفر اد فأكثر & من 5 م أفر اد الي 7 أفراد 15.868 م 115.8 & أقل = 5 أفر اد & عدد أفراد الأسرة \\
\hline & & - & أققل من 5 أفراد \\
\hline & - & $* * 42.048$ & من 5 أفراد إدلى 7 \\
\hline- & $* * 35.924$ & $* * 77.972$ & من 8 أفر اد فاكتر \\
\hline
\end{tabular}




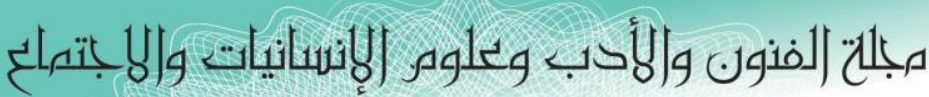
Journal of Arts, Literature, Humanities and Social Sciences

ISSN online: 2414 - 3383

ISSN print: 2616 - 3810

\section{9 نوفير \\ Volume (45)}

العدد (45)

November 2019

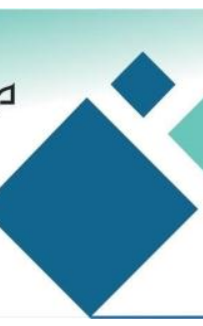

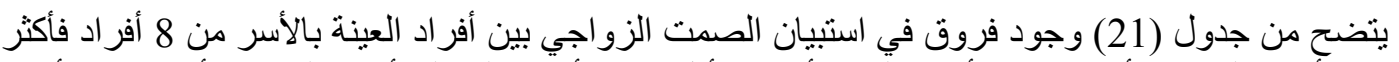

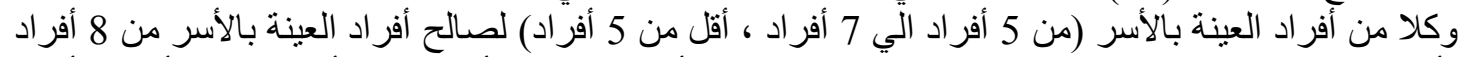

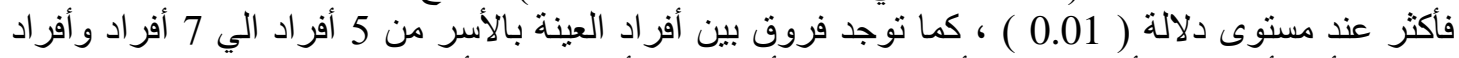

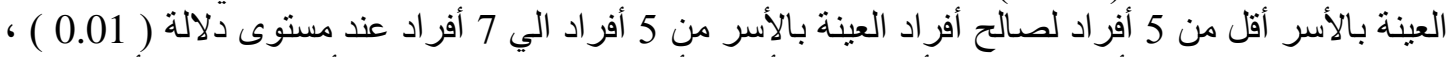

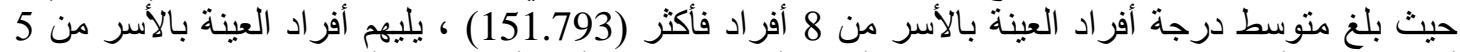

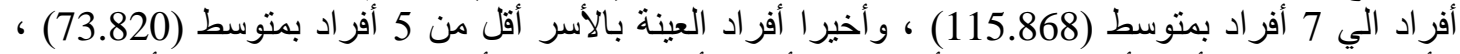

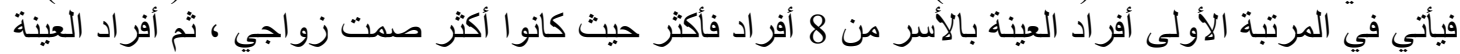

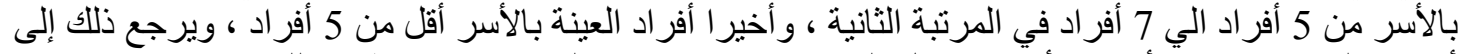

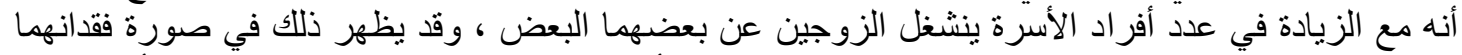

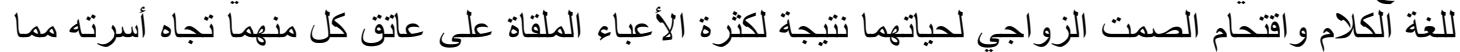
يساهم بصورة أو بأخرى في البعد بين الزوجين وملازمة الصدت الزواتئ نيجة الزي لحياتهما الزوجية.

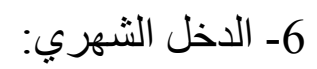

جدول (22) تحليل التباين لدرجات أفراد العينة في الصمت الزواجي تبعا لمتغير الدخل الشهري

\begin{tabular}{|c|c|c|c|c|c|}
\hline الدلالة & قيمة (ف) & الحرجية & المربعات & مجموع المربعات & الدخل الثهري \\
\hline \multirow{3}{*}{$\begin{array}{r}0.01 \\
\text { دال }\end{array}$} & \multirow{2}{*}{37.963} & 2 & 62160.197 & 124320.394 & بين المجمو عات \\
\hline & & 232 & 1637.379 & 379871.929 & داخل المجموعات \\
\hline & & 234 & & 504192.323 & المجموع \\
\hline
\end{tabular}

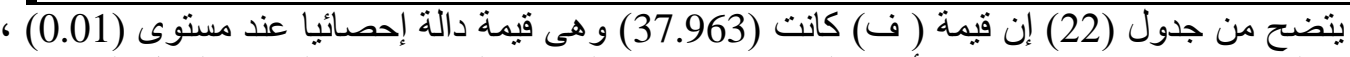

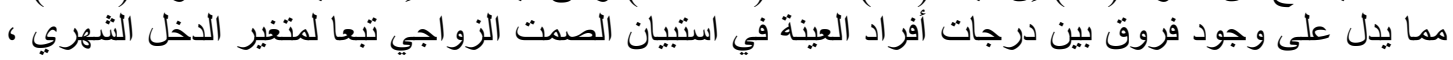

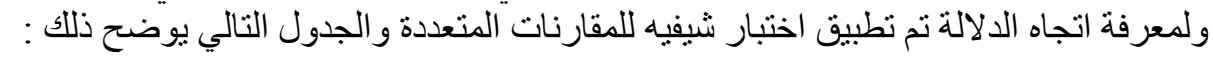

جدول (23) اختبار شيفيه للمقارنات المتعددة

\begin{tabular}{|c|c|c|c|}
\hline م = مرتفع 81.163 & م = متوسط 135.157 & م = منخفض 138.250 & الدخل الثـري \\
\hline & & - & منخفض \\
\hline & - & $* 3.092$ & متوسط \\
\hline- & **53.994 & **57.086 & مرتفع \\
\hline
\end{tabular}

بتضح من جدول (23) وجود فروق في استبيان الصدت الزواجي بين أفراد العينة ذوات الدوات الدخل المنخفض

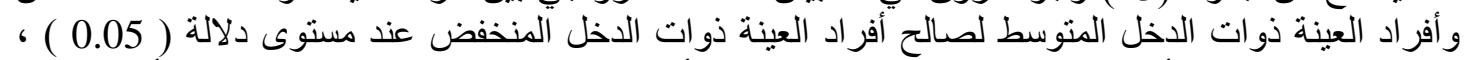

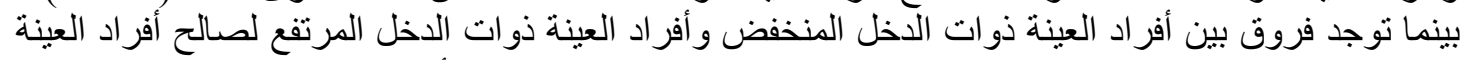

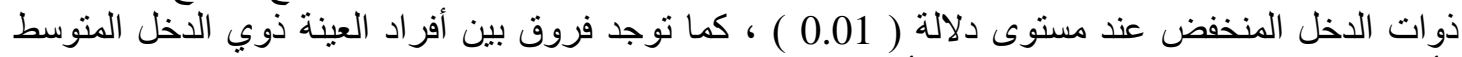

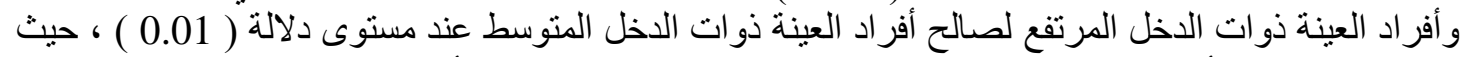

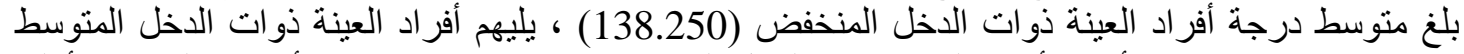

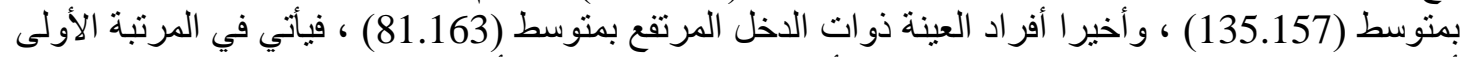

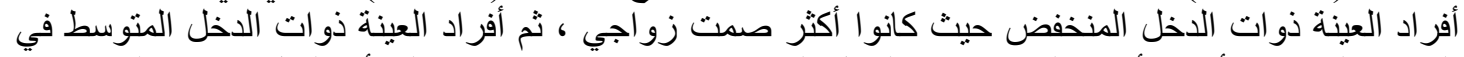

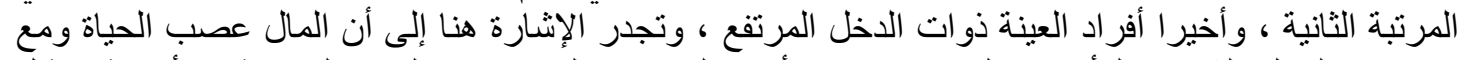

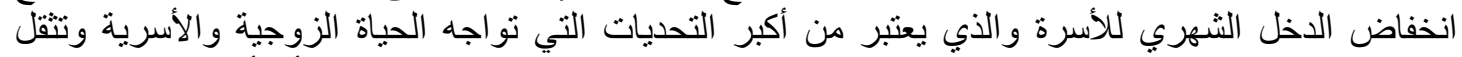

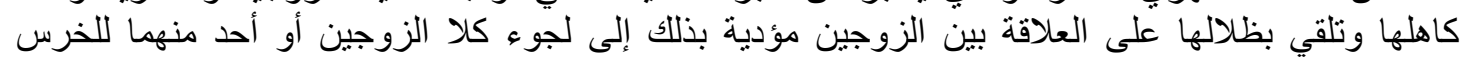




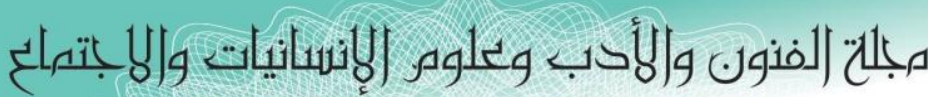
Journal of Arts, Literature, Humanities and Social Sciences

ISSN online: 2414 - 3383

ISSN print: 2616 - 3810

\section{9 نوفمبر \\ العدد (45)}

Volume (45)

November 2019

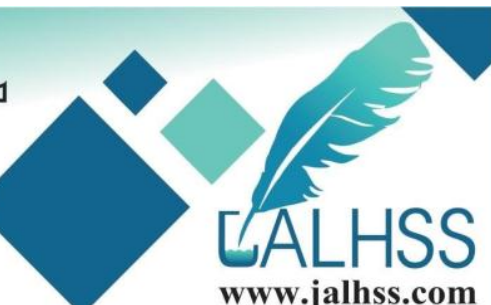

الزواجي و التزام الصدت كنوع من أنواع الحلول لمنع المواجهة والاحتدام بين الزوجين بسبب المشاكل الناتجة

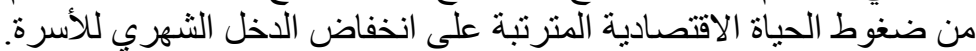

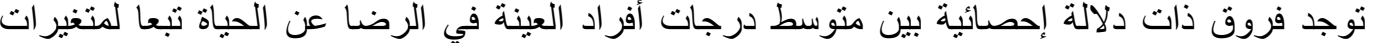

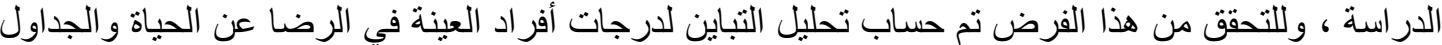

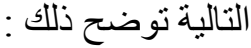

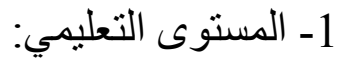
جلول (24) تحليل التباين لارجات أفراد العينة في الرضا عن الحياة تبعا لمتغير المستوي التعليمي

\begin{tabular}{|c|c|c|c|c|c|}
\hline لة الدلا & قيمة (ف) & الحرجية & متوسط المربعات & مجموع المربعات & المستوي التعليمي \\
\hline \multirow{3}{*}{1 دال } & \multirow{2}{*}{51.981} & 2 & 34535.333 & 69070.665 & بين المجمو عات \\
\hline & & 232 & 664.383 & 154136.782 & داخل المجمو عات \\
\hline & & 234 & & 223207.447 & المجموع \\
\hline
\end{tabular}

يتضح من جدول (24) إن قيمة ( ف) كانت (51.981) و هى قيمة دالة إحصائيا عند مستوى (0.01) ،

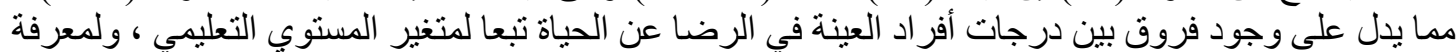

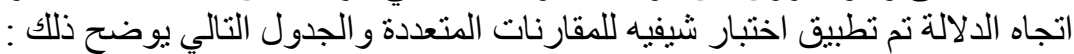

جدول (25) اختبار شيفيه للمقارنات المتعددة

\begin{tabular}{|c|c|c|c|}
\hline م = عالي & مت = متوسط 66.859 & م = منخفض & المستوي التعليمي \\
\hline & & - & منخفض \\
\hline & - & $* * 22.505$ & متوسط \\
\hline - & $* * 24.413$ & $* * 46.918$ & عالي \\
\hline
\end{tabular}

يتضح من جدول (25) وجود فروق في الرضا عن الحياة بين أفراد العينة في المستوى التعليمي العالي وكلا

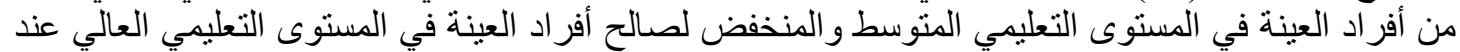

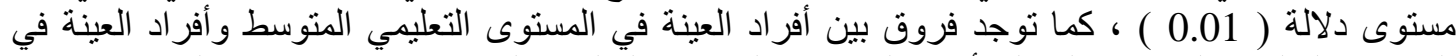

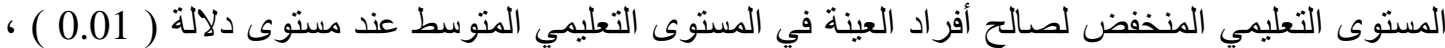

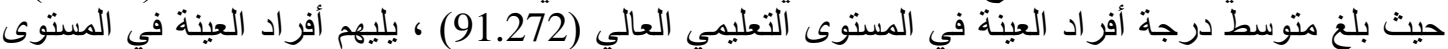

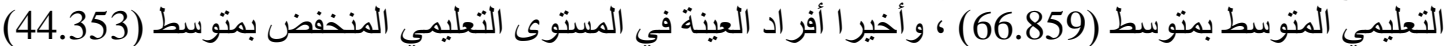

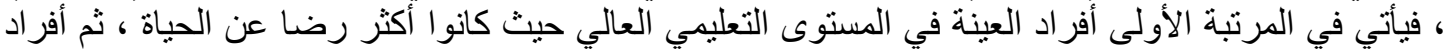

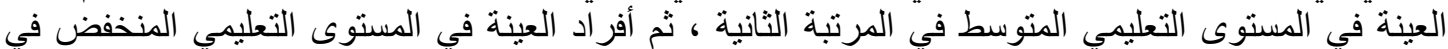

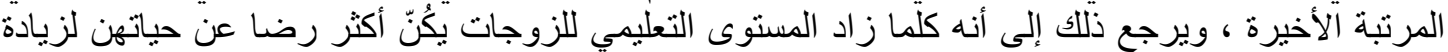

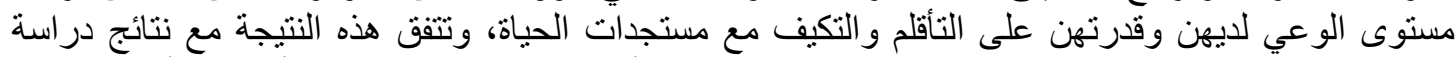

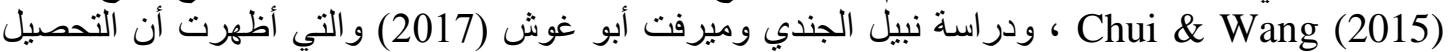
الدر اسي العالي يزيد من درجات الرضا عن الحياة للى الأشخاص. 


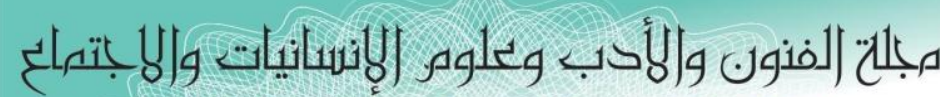
Journal of Arts, Literature, Humanities and Social Sciences

ISSN online: 2414 - 3383

ISSN print: 2616 - 3810

2019 نوف 2014 (45)
Volume

(45) العدد

November 2019

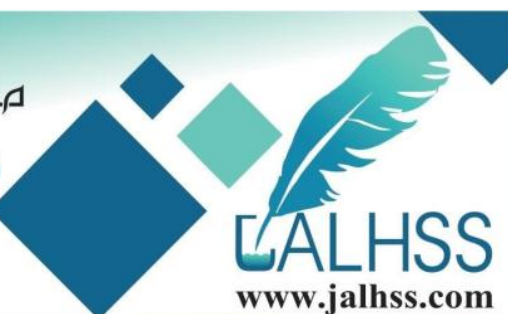

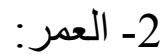

جلول (26) تحليل التباين لارجات أفراد العينة في الرضا عن الحياة تبعا لمتغير العمر

\begin{tabular}{|c|c|c|c|c|c|}
\hline الدلالة & قيمة (ف) & الحرية & متوسط المربعات & مجموع المربعات & العمر \\
\hline \multirow{3}{*}{$\begin{array}{r}0.01 \\
\text { دال }\end{array}$} & \multirow{2}{*}{41.380} & 2 & 29070.562 & 58141.123 & بين المجمو عات \\
\hline & & 232 & 702.524 & 162985.617 & داخل المجمو عات \\
\hline & & 234 & & 221126.740 & المجموع \\
\hline
\end{tabular}

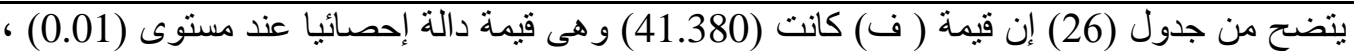

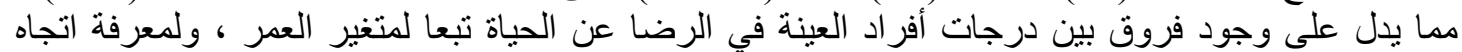

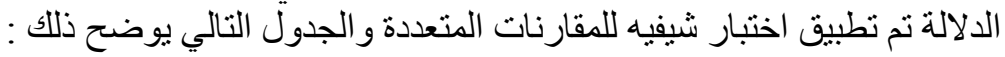

جدول (27) اختبار شيفيه للمقارنات المتعددة

\begin{tabular}{|c|c|c|c|}
\hline من 45 سنة فأكثر & من 35 سنة لأقلّ من 45 سنة & أقل من 35 سنة & العمر \\
\hline & & - & أقل من 35 سنة \\
\hline & - & $* * 27.094$ & من 35 سنة لأقل من \\
\hline- & $* * 22.158$ & $* * 49.253$ & من 45 سنة فأكثر \\
\hline
\end{tabular}

يتضح من جدول (27) وجود فروق في الرضا عن الحياة بين أفراد العينة ذوات السن السن من 45 سنة فأكثر العنر

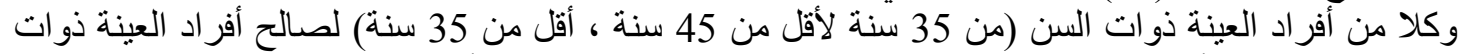

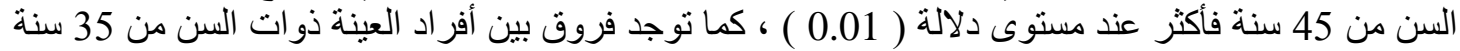

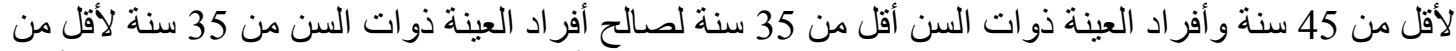

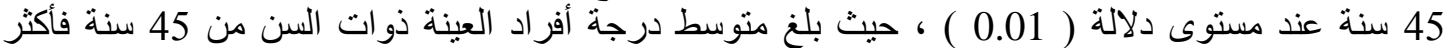

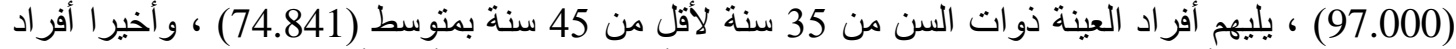

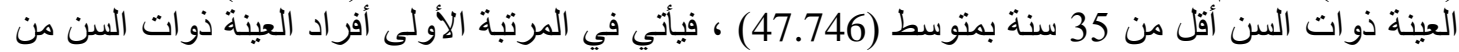

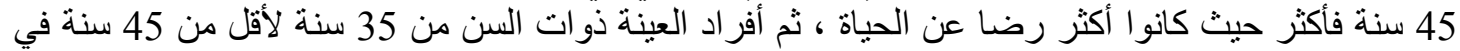

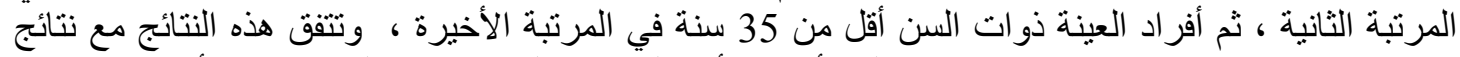

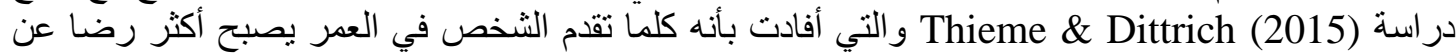
حباته.

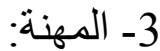

جدول (28) تحليل التباين لدرجات أفراد العينة في الرضا عن الحياة تبعا لمتفير المهنة

\begin{tabular}{|c|c|c|c|c|c|}
\hline 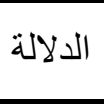 & قيمة (ف) & الحرجية & المربعات & مجموع المربعات & المهنة \\
\hline \multirow{3}{*}{ دال } & \multirow{2}{*}{31.581} & 3 & 21639.919 & 64919.758 & بين المجمو عات \\
\hline & & 231 & 685.228 & 158287.689 & داخل المجموعات \\
\hline & & 234 & & 223207.447 & المجموع \\
\hline
\end{tabular}




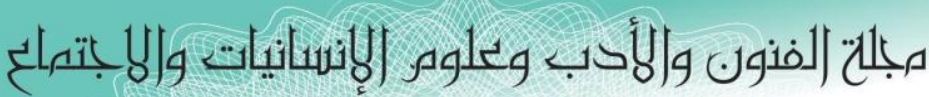
Journal of Arts, Literature, Humanities and Social Sciences

ISSN online: 2414 - 3383

ISSN print: 2616 - 3810

2019 نوفرب (45)
Volume
العدد (45)

November 2019

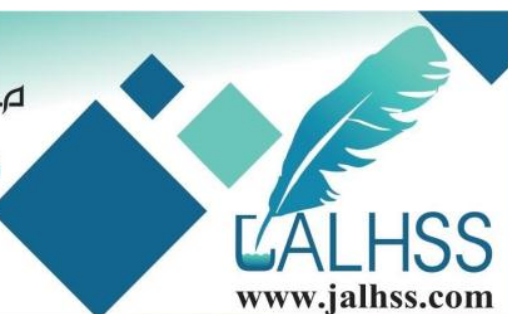

www.jalhss.com

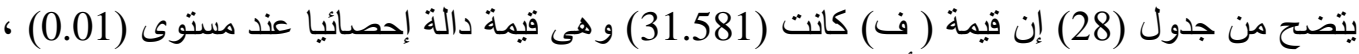

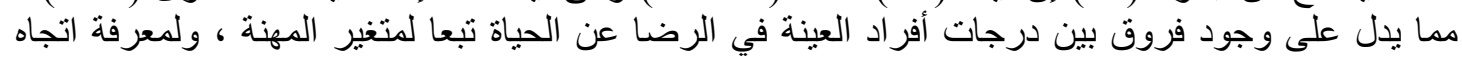

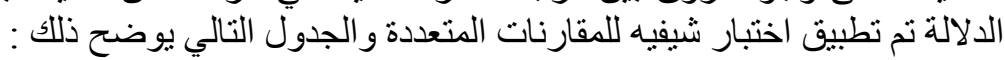

جدول (29) اختبار شيفيه للمقارنات المتعددة

\begin{tabular}{|c|c|c|c|c|}
\hline لا تعمل / متقاعدة & م = أعمال حرة & ق قطاع خاص & و = = & المهنة \\
\hline & & & - & وظيفة حكومية \\
\hline & & - & $* * 19.103$ & قطاع خاص \\
\hline & - & 1.541 & $* * 20.645$ & أعمال حرة \\
\hline - & $* * 44.370$ & $* * 42.829$ & $* * 23.725$ & لا تعمل / متقاعدة \\
\hline
\end{tabular}

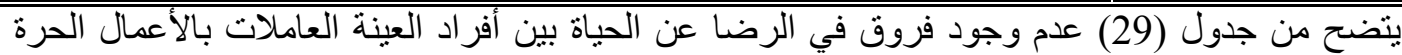

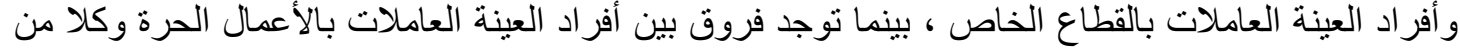

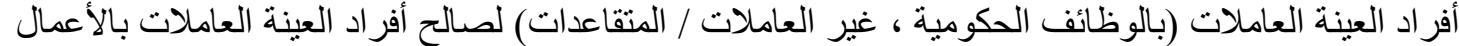

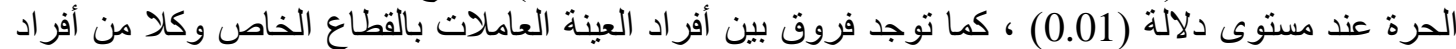

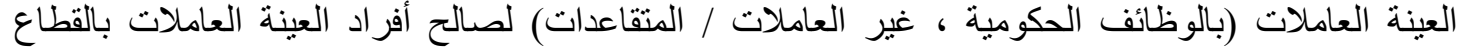

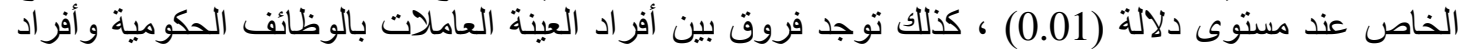

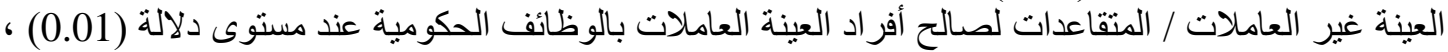

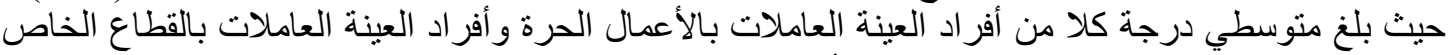

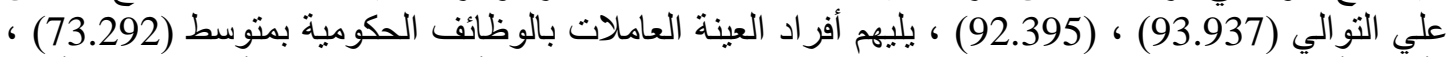

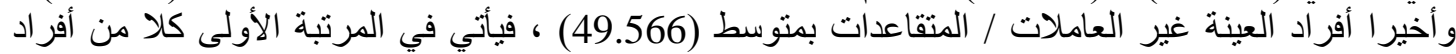

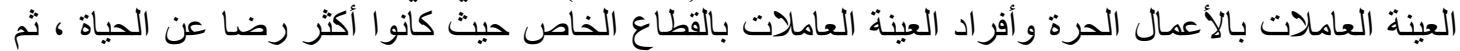

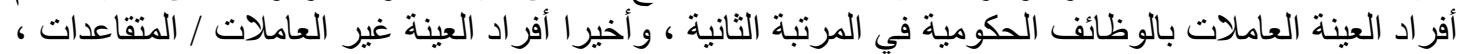

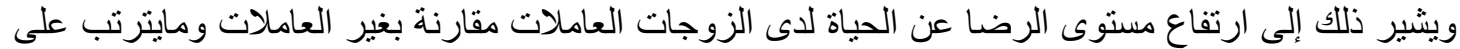

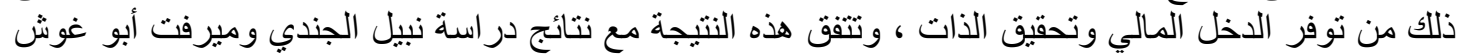

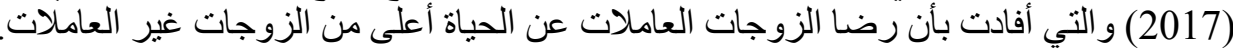

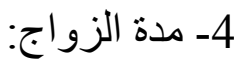

جدول (30) تحليل التباين لارجات أفراد العينة في الرضا عن الحياة تبعا لمتغير مدة الزواج

\begin{tabular}{|c|c|c|c|c|c|}
\hline الدلالة الد & قيمة (ف) & الحرية & متوسط المربعات & مجموع المربعات & مدة الزواج \\
\hline \multirow{3}{*}{$\begin{array}{r}0.01 \\
\text { دال }\end{array}$} & \multirow{2}{*}{35.071} & 2 & 23591.290 & 47182.579 & بين المجمو عات \\
\hline & & 232 & 672.663 & 156057.864 & داخل المجمو عات \\
\hline & & 234 & & 203240.443 & المجموع \\
\hline
\end{tabular}

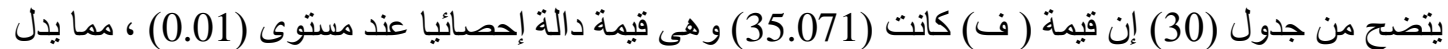

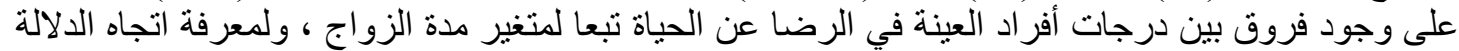
تم تطبيق اختبار شيفيه للمقارنات المتعددة والجدول فينة التنالي يوضح ذلك الكيات : 


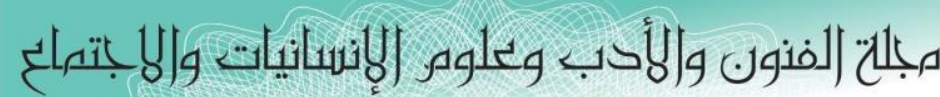
Journal of Arts, Literature, Humanities and Social Sciences

ISSN online: 2414 - 3383

ISSN print: 2616 - 3810

2019 نوفمبر

Volume (45)
العدد (45)

November 2019

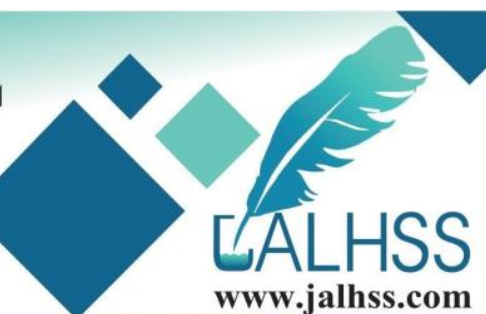

www.jalhss.com

جدول (31) اختبار شيفيه للمقارنات المتعددة

\begin{tabular}{|c|c|c|c|}
\hline من = 20 سنة فأكثر & من 10 سنو من 20 سنة إلي & أقل من 10 سنو ات 58.627 & 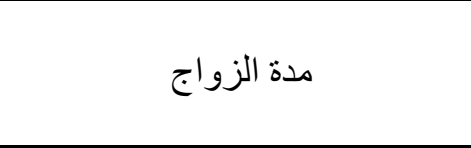 \\
\hline & & - & أقل من 10 سنو ات \\
\hline & - & $* 3.292$ & من 10 سنوات إلي أقل من 20 سنة \\
\hline- & $* * 31.705$ & $* * 34.997$ & من 20 سنة فأكثر \\
\hline
\end{tabular}

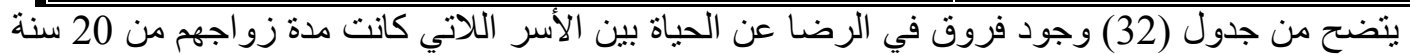

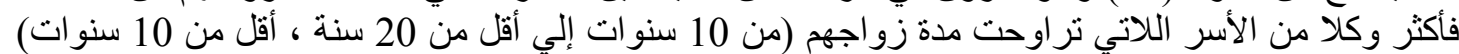

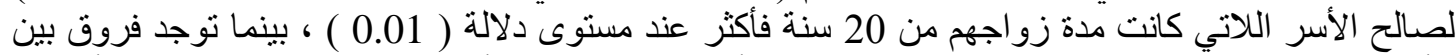

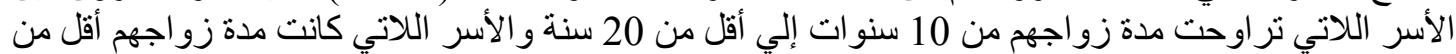

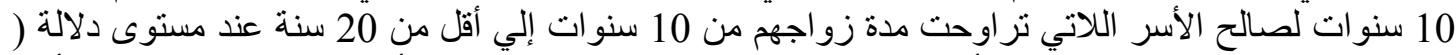

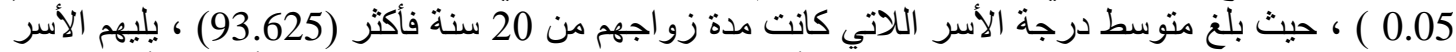

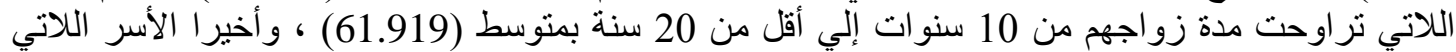

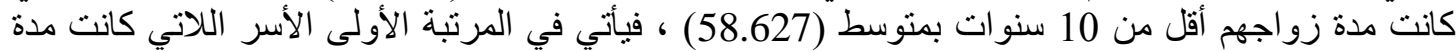

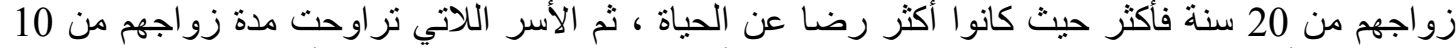

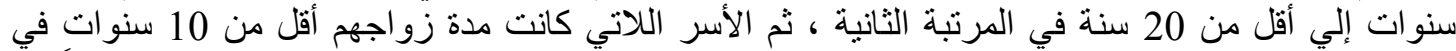

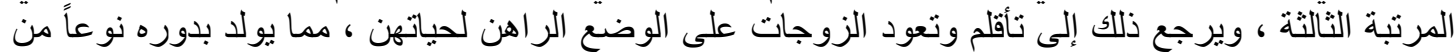
أنو اع الرضا عن الحياة و القبول بها.

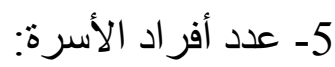

جدول (33) تحليل التباين لارجات أفراد العينة في الرضا عن الحياة تبعا لمتفير عدد أفراد الأسرة

\begin{tabular}{|c|c|c|c|c|c|}
\hline الدلالة & قيمة (ف) & الحرجية & متوسط المربعات & مجموع المربعات & عدد أفر اد الأسرة \\
\hline \multirow{2}{*}{$\begin{array}{r}0.01 \\
\text { دال }\end{array}$} & \multirow{2}{*}{33.383} & 2 & 21036.130 & 42072.260 & بين المجمو عات \\
\hline & & 232 & 630.141 & 146192.821 & داخل المجمو عات \\
\hline & & 234 & & 188265.081 & المجموع \\
\hline
\end{tabular}

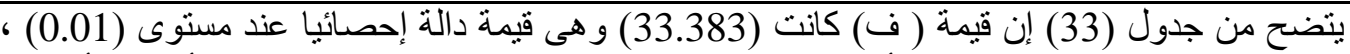

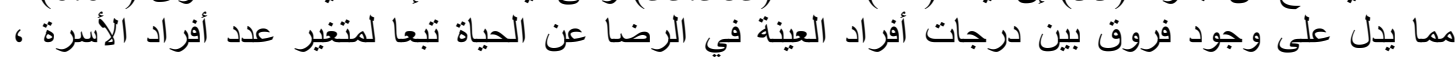
ولمعرفة اتجاه الدلالة تم تطبيق اختبار شيفيه للمقارنات المتعددة و الجدول التالي يوضئ فئ تبعح ذللك :

جدول (34) اختبار شيفيه للمقارنات المتعددة

\begin{tabular}{|c|c|c|c|}
\hline من 8 أفر اد فأكثر & من 5 أفر اد الى أفر اد & 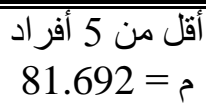 & عدد أفر اد الأسرة \\
\hline & & - & أقل من 5 أفر اد \\
\hline & - & $* 3.086$ & من 5 أفر اد إلى 7 أفر اد \\
\hline - & $* * 35.295$ & $* * 38.381$ & من 8 أفراد فأكثر \\
\hline
\end{tabular}

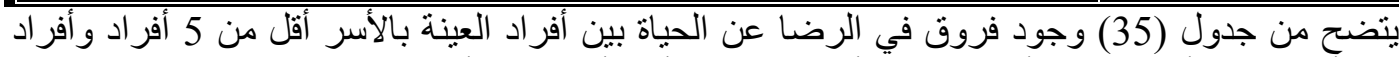

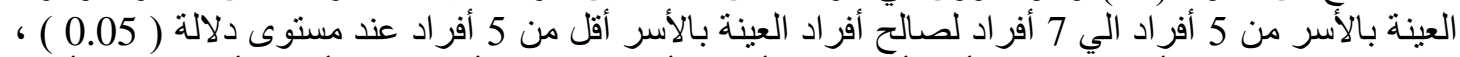
بينما توجد فروق بين أفراد آلعينة بالأسر أقل من 5 أفراد و أفراد العينة بالأسر من 8 ألفر أفراد فأكثر لصالح أفراد 


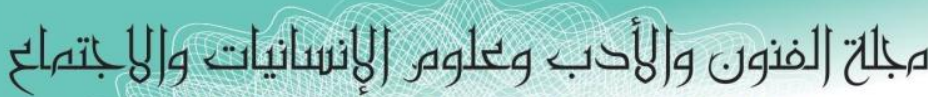

Journal of Arts, Literature, Humanities and Social Sciences

ISSN online: 2414 - 3383

ISSN print: 2616 - 3810

2019 نوفمبر

Volume (45)
العدد (45)

November 2019

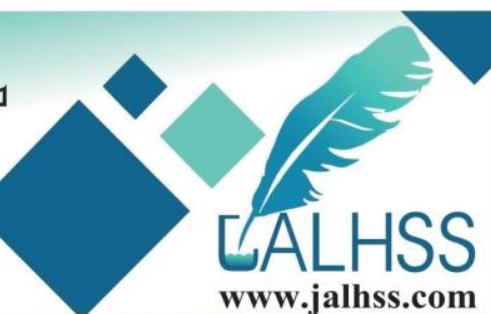

www.jalhss.com

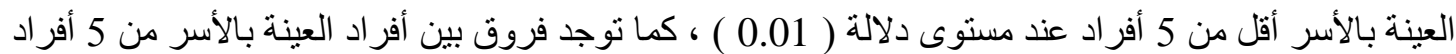

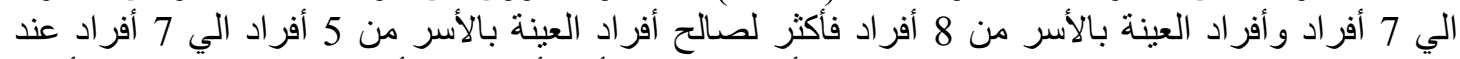

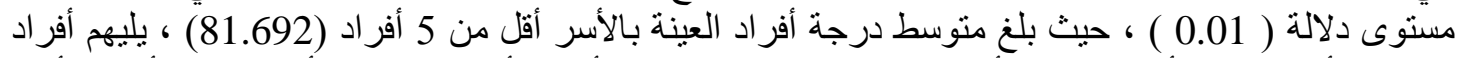

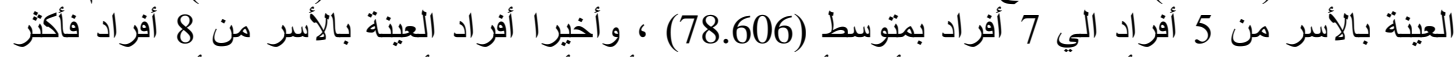

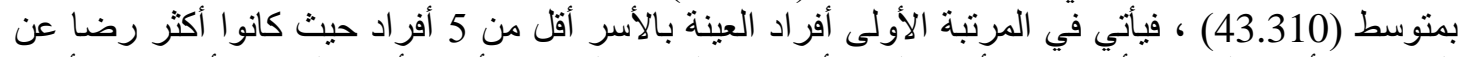

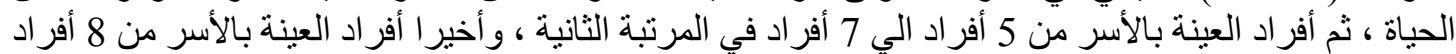

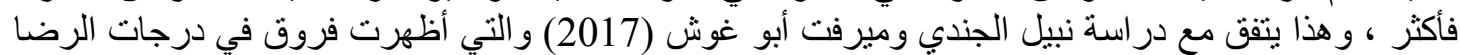
عن الحياة لصالح الأسر الأكثر عددا.

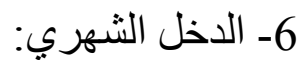

جدول (36) تحليل التباين لارجات أفراد العينة في الرضا عن الحياة تبعا لمتغير الاخل الثهري

\begin{tabular}{|c|c|c|c|c|c|}
\hline الدلالة الد & قيمة (ف) & الدرجية & المربعات & مجموع المربعات & الدخل الثهري \\
\hline \multirow{3}{*}{$\begin{array}{r}0.01 \\
\text { دال }\end{array}$} & \multirow{2}{*}{56.047} & 2 & 35231.212 & 70462.423 & بين المجمو عات \\
\hline & & 232 & 628.604 & 145836.088 & داخل المجمو عات \\
\hline & & 234 & & 216298.511 & المجموع \\
\hline
\end{tabular}

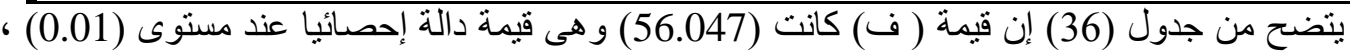

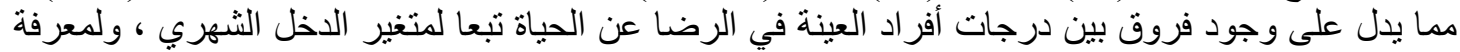

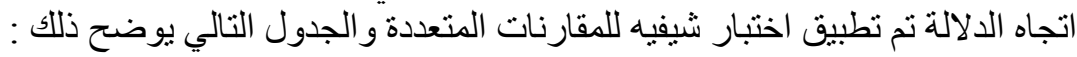

جدول (37) اختبار شيفيه للمقارنات المتعددة

\begin{tabular}{|c|c|c|c|}
\hline م = مرتفع & م = متوسط 64.789 م & م = منخفض & الدخل الثهري \\
\hline & & - & منخفض \\
\hline & - & **19.833 & متوسط \\
\hline - & $* * 25.355$ & $* * 45.189$ & مرتفع \\
\hline
\end{tabular}

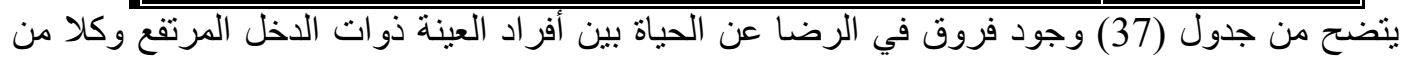

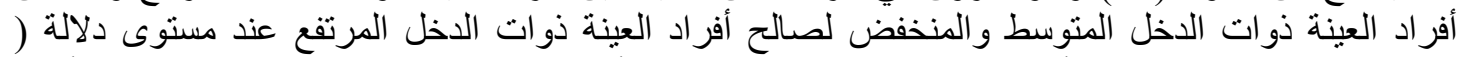

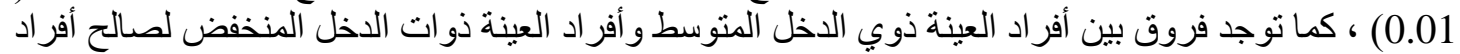

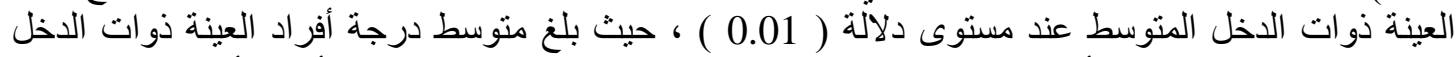

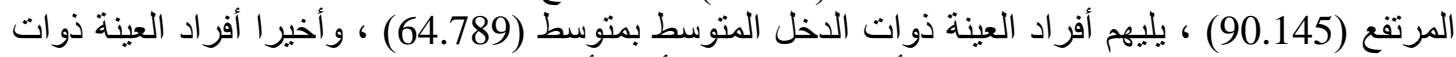

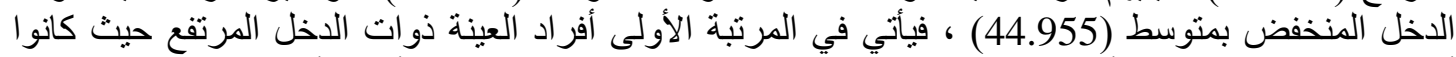

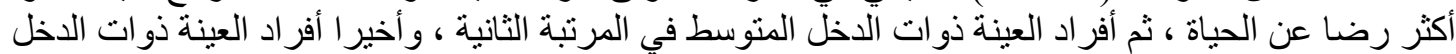

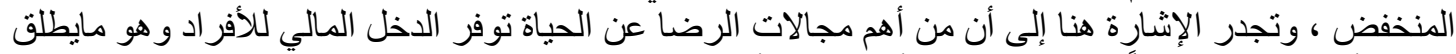

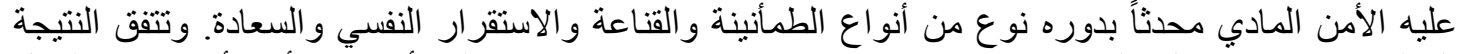

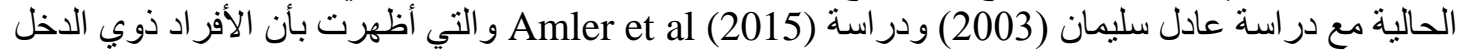
المالي المرتفع قد حققو ا درجات عالية في مقياس الرضان عندا عن الحياة . 
مجلحة لفنون والأدب وتلوه الإنسانيات و|لابتهماع Journal of Arts, Literature, Humanities and Social Sciences

ISSN online: 2414 - $3383 \quad$ (45)

ISSN print: 2616 - 3810

Volume (45) November 2019

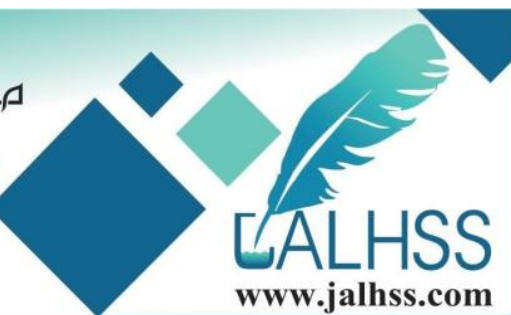

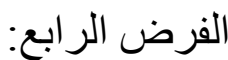

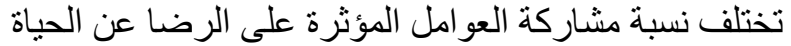

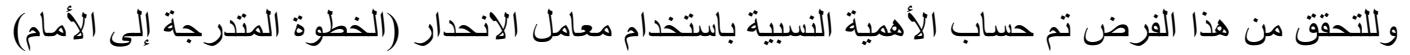

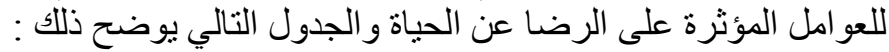

جدول (38) الأهمية النسبية باستخدام معامل الانحدار (الخطوة المتدرجة إلى الأمام)

للعوامل المؤثرة على الرضائة عن الآدار الحياة

\begin{tabular}{|c|c|c|c|c|c|c|c|c|}
\hline الدلالة & قيمة (ت) & الانحدار & للة الدلا & فيمة (ق) & المشاركة & الارتباط & المتغير المستقل & \\
\hline 0.01 & 9.936 & 0.611 & $\begin{array}{c}0.0 \\
1\end{array}$ & 98.723 & 0.779 & 0.883 & التعليمي & $\underline{E} x$ \\
\hline 0.01 & 8.621 & 0.546 & $\begin{array}{c}0.0 \\
1\end{array}$ & 74.323 & 0.726 & 0.852 & المهنة & \\
\hline 0.01 & 7.772 & 0.495 & $\begin{array}{c}0.0 \\
1 \\
\end{array}$ & 60.408 & 0.683 & 0.827 & العمر & \\
\hline 0.01 & 6.875 & 0.432 & $\begin{array}{c}0.0 \\
1\end{array}$ & 47.265 & 0.628 & 0.792 & الدخل الثهري & \\
\hline
\end{tabular}

يتضح من جدول (38) إن المستوى التعليمي كان من أكثر العوامل المؤثرة على الرضا عن الحياة بنسبة العبا

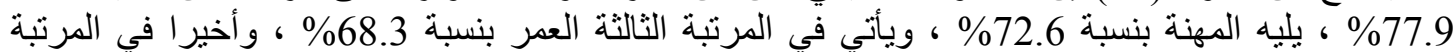
الر ابعة الدخل الثهري بنسبة 62.8\% م

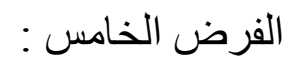

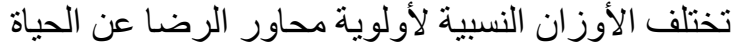
وللتحقق من هذا الفرض تم إعداد جدول الوزن النسبي التالي :

جدول (39) الوزن النسبي لأولوية محاور الرضا عن الحياة

\begin{tabular}{|c|c|c|c|}
\hline الترتيب & النسبة المئوية\%\% & الوزن النسبي & الرضـا عن الحياة \\
\hline الر ابع & $\% 16.2$ & 268 & السعادة \\
\hline السادس & $\% 14.6$ & 241 & الاجتماعية \\
\hline الثالث & $\% 17.1$ & 284 & الطمأنبنة \\
\hline الثاني & $\% 18.1$ & 299 & الاستقر ار النفسي \\
\hline الخامس & $\% 15.5$ & 257 & التقدير الاجتماعي \\
\hline الأول & $\% 18.5$ & 307 & القناعة \\
\hline & $\% 100$ & 1656 & المجموع \\
\hline
\end{tabular}

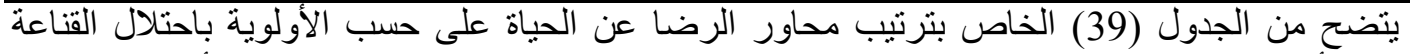

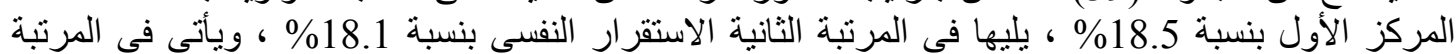

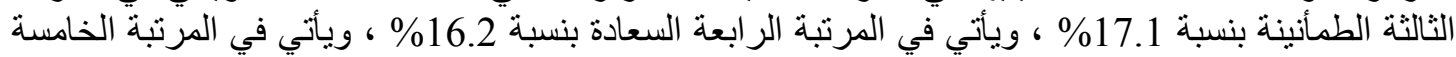
التقدير الاجتماعي بنسبة 15.5\% ، 17 و ويأتي في المرتبة السادسة الاجتماعية بنسبة 14.6\% 


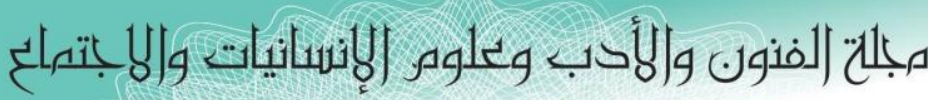
Journal of Arts, Literature, Humanities and Social Sciences

ISSN online: 2414 - 3383

ISSN print: 2616 - 3810

2019 نوفمبر

Volume (45)
العدد (45)

November 2019

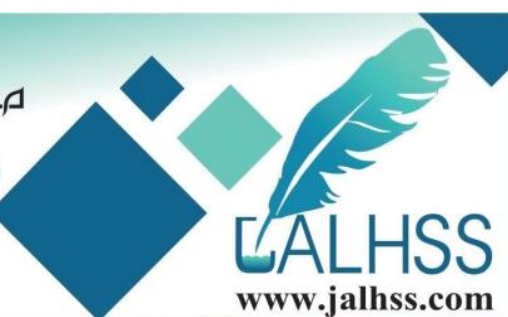

قياس درجة الصمت الزو اجي

جلول (40) يوضح قياس درجة الصمت الزواجي

\begin{tabular}{|c|c|c|c|c|c|c|c|c|}
\hline \multicolumn{2}{|c|}{ المجموع } & \multicolumn{2}{|c|}{ 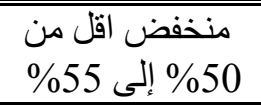 } & \multicolumn{2}{|c|}{ 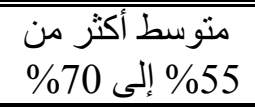 } & \multicolumn{2}{|c|}{ أكثر من مرتفع } & \\
\hline النسبة \% & العدد & النسبة\% & العدد & النسبة\% & العدد & النسبة\%\% & العدد & \\
\hline$\% 100$ & 235 & $\% 17.4$ & 41 & $\% 50.2$ & 118 & $\% 32.3$ & 76 & ككل الاستبيان \\
\hline
\end{tabular}

يتضح من الجدول (40) أن درجة الصمت الزو اجي المرتفع كانت تمثل نسبة 32.3\% ؛

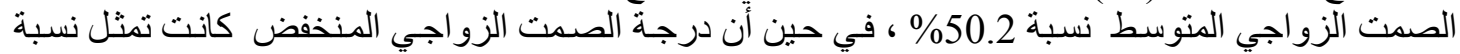
17.4 مما يدل على وجود ظاهرة الصمت الزو اجي لدى عينة البحث .

التوصيات :

1. العمل على توفير البيئة الحوارية المحفزة للتواصل الزواجي وذللك بتحديد مساحة زمنية للنقاش وتبادل

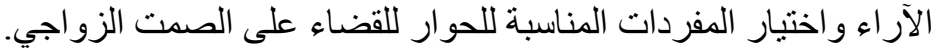

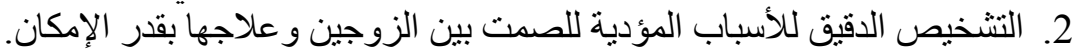

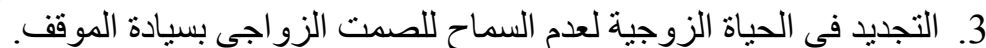

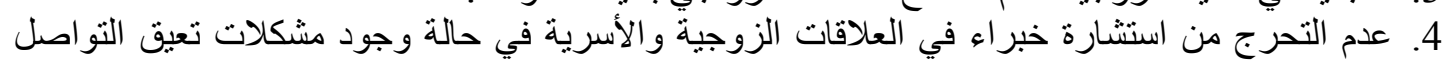

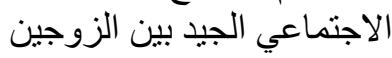

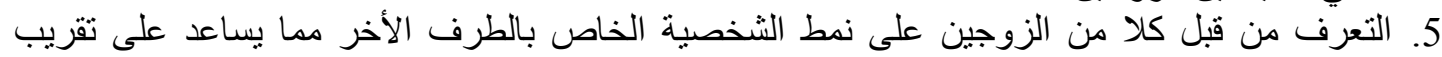

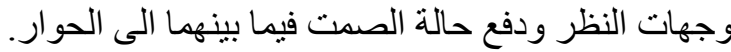

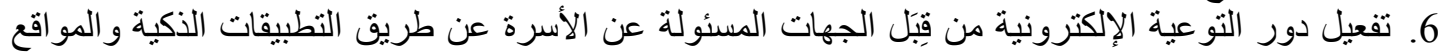

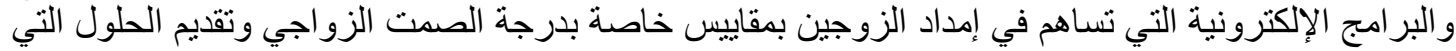
تساهم في القضاء عليه.

\section{المراجع العربية}

1. ذوقان عبيدات و عبد الرحمن عدس و كايد عبد الحق (2016) : البحث العلمي مفهومه أدو اته أساليبه ،

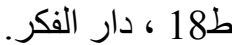

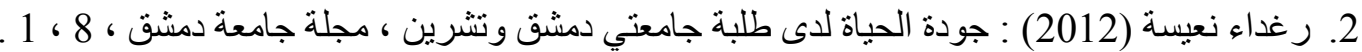

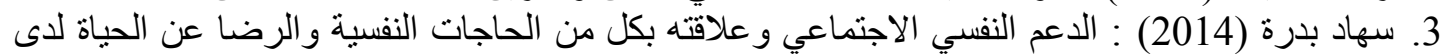

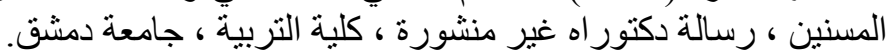

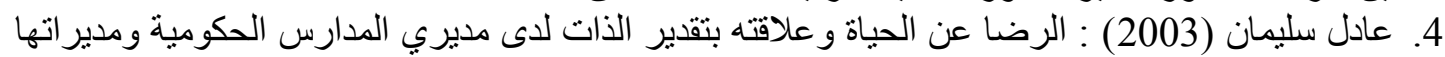

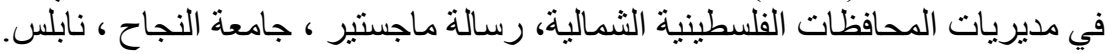

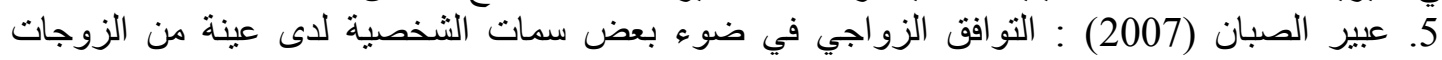

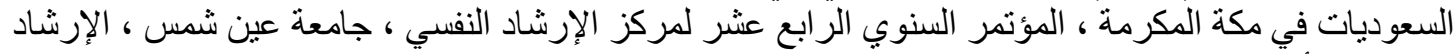
النفسي من أجل التنمية في ظلل الجودة الثناملة (توجيهات الترات مستقبلية).

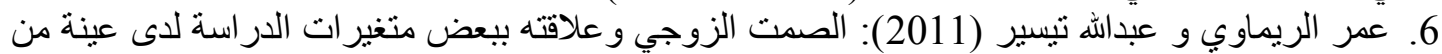

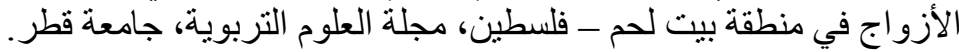
7. كمال مرسي (2000) : السعادة وتنمية الصحة النفسية ، مصر دار النشر للجامعات ، طانس. 


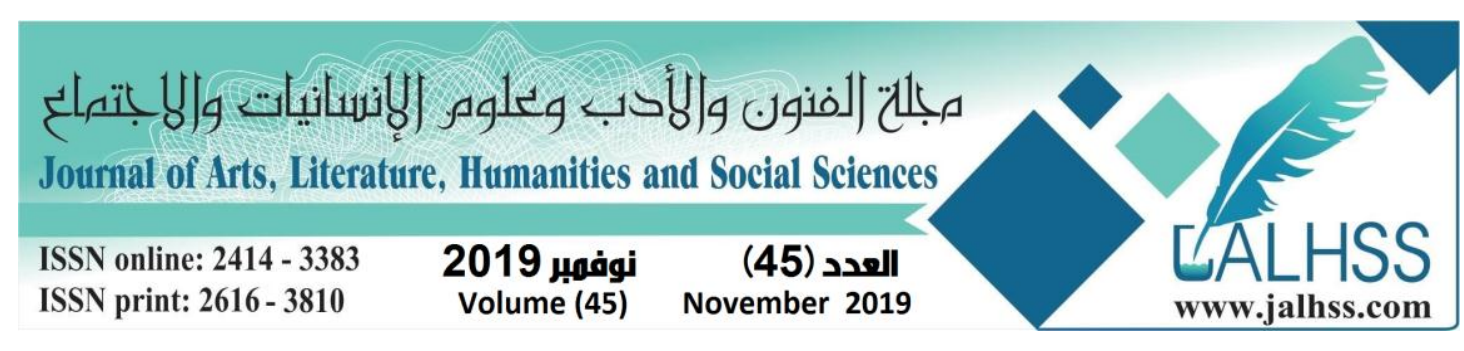

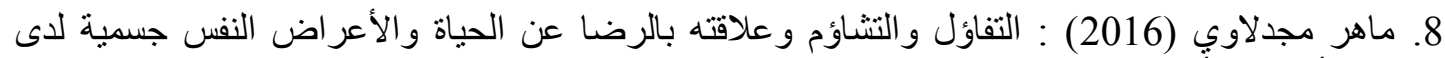

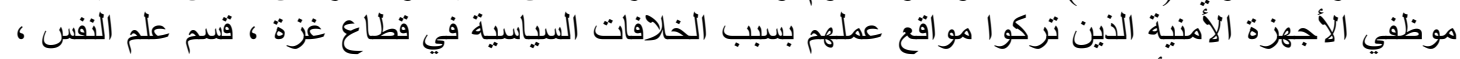
كلية التربية ، جامعة الأقصىى. 9. مجدي دسوقي (2013) : مقياس الرضا عن الرئية الرياة ، مكتبة الأنجلو المصرية.

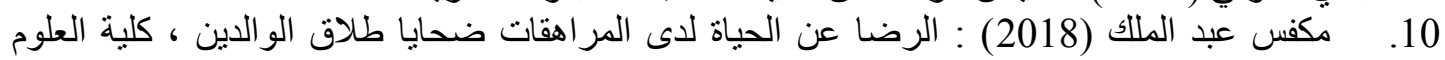
الإنسانية ، جامعة محمد بوضياف ، المسيلة ، الجز ائر. 11. الأزو اج في الضفة الغربية ، البلقاء للبحوث و الدراسات، مجلة علمية محكمة متخصصة، المجلد 20، العدد 1 ،

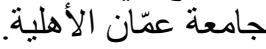

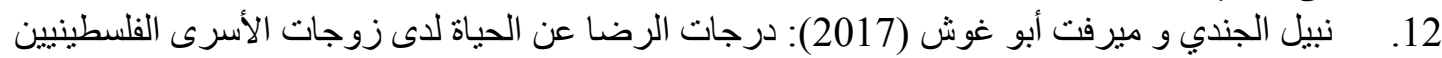

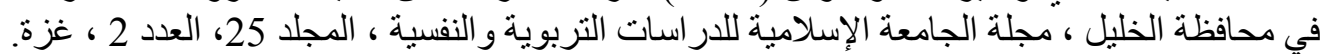

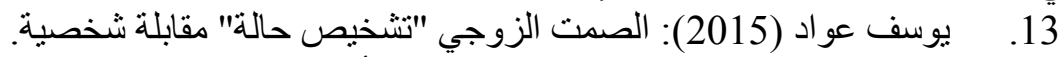

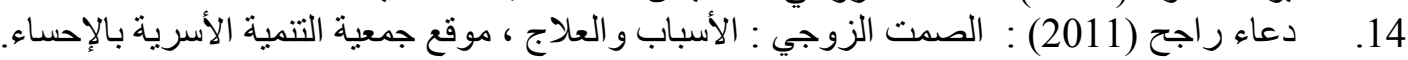
http://www.osarya.com/index.php/2011-09-23-11-31-21/2011-09-23-11-57-52/654.2011-12-18-13-40-16.html

$$
\text { 15. }
$$

https://pulpit.alwatanvoice.com/content/print/377643.html

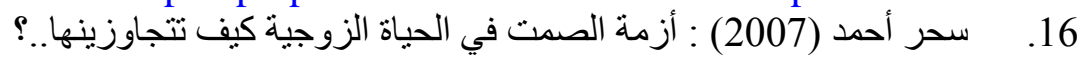
https://www.alukah.net/social/0/408/ 17.

http://www.grenc.com/show_article_main.cfm?id=17488

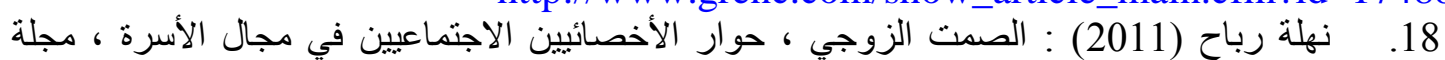

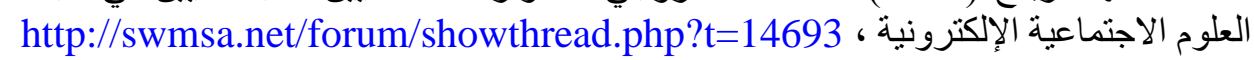

\section{References}

1. Touqan Obeidat and Abdul Rahman Adas and Kayed Abdelhaq (2016): Scientific research concept of tools and methods, Dar Al-Fikr.

2. Raghida Na'isah (2012): Quality of Life of Damascus and Tishreen University Students, Journal of Damascus University, 8, 1.

3. Suhad Badra (2014): Psychosocial support and its relationship to both psychological needs and life satisfaction in the elderly, unpublished doctoral thesis, Faculty of Education, Damascus University.

4. Adel Suleiman (2003): Satisfaction with life and its relationship with self - esteem in the principals of public schools and their principals in the directorates of the northern Palestinian governorates, Master Thesis, An - Najah University, Nablus.

5. Abeer Al-Sabban (2007): Marital compatibility in the light of some personality traits of a sample of Saudi wives in Makkah, 14th Annual Conference of Psychological Counseling Center, Ain Shams University, Psychological Counseling for Development under Total Quality (Future Guidance).

6. Omar Rimawi and Abdullah Tayseer (2011): Matrimonial silence and its relationship to some study variables among a sample of couples in Bethlehem Palestine, Journal of Educational Sciences, Qatar University.

7. Kamal Morsy (2000): Happiness and the Development of Mental Health, Egypt. 


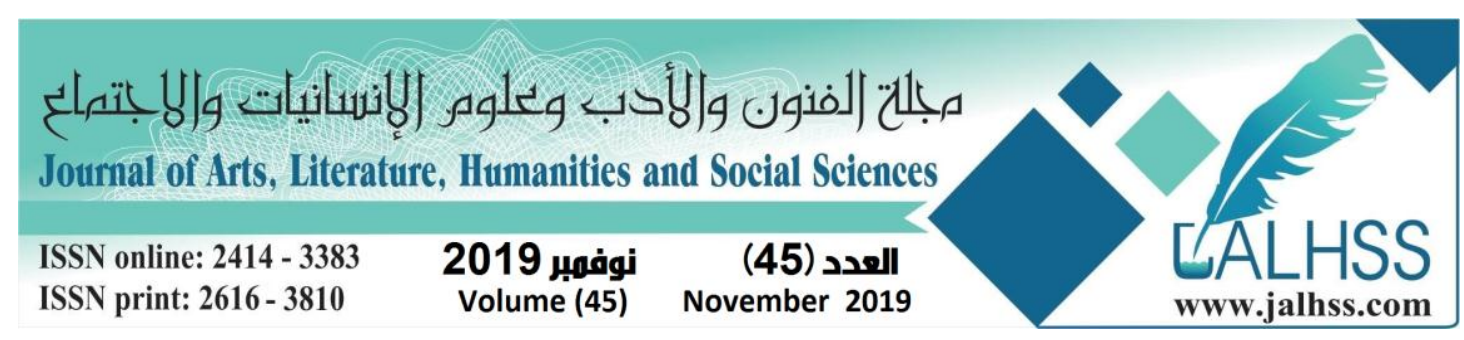

8. Maher Majdalawi (2016): Optimism and pessimism and its relationship to life satisfaction and physical symptoms of physical security staff who left their positions due to political differences in the Gaza Strip, Department of Psychology, Faculty of Education, Al-Aqsa University.

9. Magdy Desouky (2013): Life Satisfaction Scale, Anglo-Egyptian Library.

10. Mkfs Abdelmalek (2018): Satisfaction with life among adolescent victims of parental divorce, Faculty of Humanities, Mohamed Boudiaf University, M'Sila, Algeria.

11. Nabil al-Jundi and Maha Abu Znaid (2017): Matrimonial Silence and its Relationship with Psychological Compatibility among a Sample of Couples in the West Bank, Al-Balqa Research and Studies, A Scientific Refereed Journal, Vol. 20, No. 1, Amman Private University.

12. Nabil al-Jundi and Mervat Abu Ghosh (2017): Degrees of Life Satisfaction among the Wives of Palestinian Prisoners in Hebron Governorate, Islamic University Journal for Educational and Psychological Studies, Vol. 25, No. 2, Gaza.

13. Yousef Awwad (2015): Marital Silence "Diagnosing a Case" Personal Interview.

19. Amler, S. Sauerland, M., Deiters, Ch., Buchner, Th., Schumacher, A. (2015) : Factors influencing life satisfaction in acute myeloid leukemia survivors following allogeneic stem cell transplantation, a cross-sectional study, Health and Quality of life Outcomes.

20. Chui, H. \& Wong, M. (2015) : Gender Differences in Happiness and Life Satisfaction among Adolescents in Hong Kong, Relationships and Self-concept. Springer Science + Business Media Dordrecht.

21. Pinquart, M, \& Teubert, D. (2010) : Ameta - analytic Study of Couple Interventions During the Transition to parenthood. Family Relation, 59 (3) .

22. Thieme, P. \& Dittrich, A. (2015) : A life-span perspective on life satisfaction. Social Science Research Network (SSRN).

23. Doaa Rajeh (2011): Matrimonial Silence: Causes and Treatment, Family Development Association in Al-Ahsa. http://www.osarya.com/index.php/2011-09-2311-31-21-2011-09-23-11-57-52/654-2011-12-18-13-40- 16.html.

24. Sari Al-Nashwi (2015): Matrimonial Silence, Causes and Treatment https://pulpit.alwatanvoice.com/content/print/377643.html

25. Sahar Ahmed (2007): The crisis of silence in married life How to overcome ...? https://www.alukah.net/social/0/408/
26. Mohamed
Kansou
(2010):
Doubtless
Mute,

http://www.grenc.com/show_article_main.cfm?id=17488

27. Nahla Rabah (2011): Matrimonial Silence, Social Workers' Dialogue in the Family, Electronic Social Science Journal, http://swmsa.net/forum/showthread.php?t=14693 